\title{
Re-Inhabiting Inner Areas Triggering New Regeneration Trajectories: The Case Study of Sicani in Sicily
}

\author{
Barbara Lino ${ }^{1, *}$, Annalisa Contato ${ }^{1}$, Mauro Ferrante ${ }^{2} \mathbb{D}$, Giovanni Frazzica ${ }^{2}$, Luciana Macaluso ${ }^{1}$ (D) \\ and Francesca Sabatini ${ }^{2}$ \\ 1 Department of Architecture, University of Palermo, 90128 Palermo, Italy; annalisa.contato@unipa.it (A.C.); \\ luciana.macaluso@unipa.it (L.M.) \\ 2 Department of Culture and Society, University of Palermo, 90128 Palermo, Italy; \\ mauro.ferrante@unipa.it (M.F.); giovanni.frazzica@unipa.it (G.F.); francesca.sabatini@unipa.it (F.S.) \\ * Correspondence: barbara.lino@unipa.it; Tel.: +39-347-832-0956
}

check for updates

Citation: Lino, B.; Contato, A.; Ferrante, M.; Frazzica, G.; Macaluso, L.; Sabatini, F. Re-Inhabiting Inner Areas Triggering New Regeneration Trajectories: The Case Study of Sicani in Sicily. Sustainability 2022, 14, 976. https://doi.org/10.3390/su14020976

Academic Editors: Diana Rolando, Manuela Rebaudengo and Alice Barreca

Received: 14 December 2021

Accepted: 12 January 2022

Published: 15 January 2022

Publisher's Note: MDPI stays neutral with regard to jurisdictional claims in published maps and institutional affiliations.

Copyright: (c) 2022 by the authors. Licensee MDPI, Basel, Switzerland. This article is an open access article distributed under the terms and conditions of the Creative Commons Attribution (CC BY) license (https:// creativecommons.org/licenses/by/ $4.0 /)$.

\begin{abstract}
The Italian debate on the so-called 'inner areas' has received a much-needed boost, following the COVID-19 pandemic, which has further highlighted the differences between metropolitan and inner areas. While the progressive depopulation of inner areas is a worrying phenomenon, the limits of incessant urbanisation and the concentration of settlement and infrastructure policies in large conurbations have become evident. Departing from the framework of the B4R-Branding4Resilience research project of national interest and, by continuing in the furrow initiated by the SNAI, but also surpassing it, the aim of the University of Palermo's research is to define the requirement for a more inclusive settlement model in the Sicani area in Sicily (Italy) to re-balance existing asymmetries by recharging peripheral areas with new centrality. The aims of the research are to demonstrate that inner areas could be an engine for innovation, thereby outlining a roadmap through which to encourage the resilience of new sustainable lifestyles. These aims would be achieved by working on new perspectives and projects, which are capable of radically modifying production, consumption, and tourism dynamics and work/life models, and which are gleaned from a study regarding the Sicani area in Sicily. The paper discusses case study quantitative and qualitative analyses and first results.
\end{abstract}

Keywords: territorial resilience; sustainable development strategies; inner areas

\section{Introduction}

\subsection{The General Theoretical Framework: Re-Inhabiting Inner Areas}

In recent years, finding perspectives for inner peripheries is a highly relevant contemporary issue in the European regional policy and academic discourses.

In the evolution of the theoretical contextualization, the concept of inner peripheries which is emerging departs from the hard economic potential which characterised early peripherality modelling [1-3], and it is more linked with the position of the sociological literature on the phenomena of peripherality [4] and demographic issues (such as ruralurban migration, and ageing), with a softer, socio-economic focus on services of general interest and associated to the well-being of communities. According to the ESPON's PROFECY project results [5] inner peripheries are a complex, multidimensional and a hybrid phenomenon, which is extremely flexible in terms of its context and scale. These areas can be enclaves of low economic potential, or experience poor access to services of general interest or a lack of relational proximity. These primary processes act as a driver, but a range of secondary marginalisation processes exacerbate the situation. Peripherality in this understanding is not a purely geographic concept, but rather refers to the effects of socio-economic processes that cause disconnection with neighbouring territories and networks in a relational way.

In Italy, after the process that since the 1950s led to the gradual abandonment of inner areas, and despite the constant presence of the metropolitan dimension in public 
policies, the territories on the margin have returned to become visible through public and collective actions in recent years [6]. The Italian national strategy named 'Strategia Nazionale Aree Interne' (SNAI) represents an existing and emerging governance approach looking at official authorities but also at informal governance groups to overcome the classic opposition between the rural and the urban. The SNAI has directed the attention of Italian policymakers towards the need for improving the socio-economic conditions of the people living in inner areas: remote municipalities suffer from a lower availability of essential services (e.g., education, health, mobility), population shrinkage, reduction of economic activities, and social disruption) [7]. In this strategy, the so called 'aree interne' are conceived as rural areas subject to strong centrifugal forces, demographic decline, migration, abandonment of the use and management of land, natural hazards, isolation, low accessibility to services and infrastructure, and economic marginalization. The SNAI has overturned the debate on the paradigms of the past, going beyond the opposition of city/countryside, and provides important lessons in terms of: the need to give prominence to the territories and space for their co-design; the reconstruction of new identities and renewed confidence in marginal areas; and the importance of reintroducing the territory into the policy horizon accompanying a process that guarantees access to basic services and promotes medium/long-term policies attentive to the specificities of contexts with a place-based approach.

Today, the experience of the COVID-19 pandemic has rekindled the debate on inner areas, sometimes with lingering anti-urban utopias and sweetened 'escapes from the city', but above all reinforcing the perception of those territorial inequalities between metropolitan and inner areas exacerbated by the crisis. The pandemic has highlighted in all its rawness territorial differences, in terms of services such as hospitals and medical assistance and the digital divide.

The SNAI (recently included among the 55 actions defined by the Italian government for the post-COVID-19 economic recovery plan within the next generation) should be pursued and even surpassed, for example, by starting from the spatialisation of policies that reactivate marginal spaces, not necessarily coinciding with the inner areas alone, and that place themselves at an observation point 'not from the "centres" towards the "margins", but from the "margins" themselves' [8] (p. 51). Italy must commit itself to overcoming territorial disparities that are no longer acceptable [9], by supporting territorial policies in which marginal areas find a renewed centrality [10].

In the face of obvious social, infrastructural, and economic disadvantages, in several cases some communities of the inner areas are already trying to 'diversify themselves locally' by leveraging relevant enabling contextual conditions, such as: strong local identities in terms of quality of life, architectural, and natural quality; a wide range of exploitation of social and territorial capital in terms of both physical and human resources; and the accessibility of the real estate market and low cost of buildings, in front of a high architectural quality and typical characters to recover [11].

Although the target of self-sufficiency, which once nourished so many anti-urban utopias, has often fuelled a radically opposing view between inner areas and metropoli$\tan$ areas, today we recognize the need for a more inclusive settlement model capable of rebalancing existing asymmetries. Metropolitan cities and inner territories may be 'opposites' in terms of living and working conditions, but they should cooperate and become interdependent, while preserving their different identities. These areas 'must be thought of and planned, on the one hand, as recipients of collective goods and services, and, on the other, as areas capable of producing and offering collective goods, which respond to needs expressed by the whole of society, and which take the form of services capable of strengthening new links between inland areas and cities' [12] (p. 146).

The small centres of the inner areas can become an extended cooperative system of centres linked to productive territories and metropolitan cities, new rural-urban archipelagos in which each municipality shares dwellings, public spaces, and facilities, which can contribute to balancing rural, urban and territorial development [13]. 
The peripherality of inner areas cannot be interpreted in the unilateral category of socio-economic delay but should be also translated as including cultural potential, social and territorial identities, place-based capitals, and community-driven traditional values.

Inner areas could be an engine for innovation, encouraging resilience for new sustainable lifestyles and working on new perspectives and projects, which are capable of radically modifying production, consumption, tourism dynamics, and work/life models.

\subsection{The Objectives of the Research: Branding for Resilience and the Sicani Case Study in Sicily}

The theoretical framework outlined above calls for the need to change the current imagery and make room for positions and areas of interest that can trigger new development dynamics in inner areas.

The research project 'B4R Branding4Resilience. Tourist infrastructure as a tool to enhance small towns by drawing resilient communities and new open habitats' is a research project of national interest (PRIN 2017 Young Line) funded by the Ministry of Education, University and Research (MIUR) with a three-year duration (2020-2023). The project is coordinated by the Università Politecnica delle Marche (National Coordinator Maddalena Ferretti), and it involves as partners the Università degli Studi di Palermo (Local Coordinator Barbara Lino), the Università di Trento (Local Coordinator Sara Favargiotti), and the Politecnico di Torino (Local Coordinator Diana Rolando). This project takes on this change of perspective by addressing marginal areas as drivers of innovation and test fields for new development dynamics, looking at the potentials and resources specifically related to space, settlements, and landscapes [14].

The project aims to develop exploratory scenarios [15] and relational models that can open up design-driven knowledge production for broader spatial strategies that support administrations in formulating development policies.

In the understanding of the research project, branding is a complex socio-political construct, composed of a multiple interdependency in spatial and temporal dimensions, among actors, different types of users, and stakeholders.

Within the framework of the research project B4R Branding4Resilience, the Research Unit of the University of Palermo works in Sicani territory in Southern Sicily, focusing on the topic of 'co-creative communities'. Despite the evidence of marginality, such as a low density, ageing population, increasing emigration, and socio-economic weaknesses, the area has several experiences that are generating an innovative social dimension: new ecocreative communities and neo-rural practices are emerging, such as repopulation processes resulting from public policies, private initiatives, and relational tourism experiences.

In this paper we describe the results of the analysis of the Sicilian case study area made from a series of on-site assessments and GIS mapping, grounded in a transdisciplinary approach that integrates urban planning, geography, sociology, and statistics perspectives and methods.

The study offers a framework for the region's development and manages to describe a path to activate 'reserves of resilience' for new sustainable lifestyles. The settlement development options that the study displays can be used as a model for similar considerations in comparable regions of Europe.

\section{Materials and Methods}

\subsection{The Sicani Inner Area: A Case Study}

Within the framework of the B4R research project, the Research Unit of the University of Palermo explores the small towns and their communities in the Sicani territory in Southern Sicily (B. Lino and A. Contato have been involved in research activities of the Local Development Laboratory (SicaniLab) of the 'Polo Universitario di Ricerca di Bivona e Santo Stefano Quisquina per l'energia, l'ambiente e le risorse del territorio'. The SicaniLab, coordinated by Professor Maurizio Carta, carried out a research in the Sicani Inner Area and different studies for territorial and local development. See: Lino, B. [2017] A New Rur-Urban Utopia? Social innovation and the case of the Sicani area in Sicily. In Territories. 
Rural-Urban strategies; Schröder, J.; Carta, M.; Ferretti, M.; Lino B. (Eds.); Jovis Verlag GmbH: Berlin, German, pp. 110-117; Contato, A. [2018] 'The Peripheri-City of the Inner Areas: Local Development in the Sicani Territory'. In Dynamics of Periphery. Atlas for Emerging Creative Resilient Habitats; Schröder, J.; Carta, M.; Ferretti, M.; Lino B. (Eds.); Jovis Verlag GmbH: Berlin, German, pp. 192-199) [16,17]. The Focus Area (FA) is composed of 18 municipalities and located halfway between the cities of Palermo and Agrigento from north to south and between the cities of Trapani and Caltanissetta from west to east, as shown in Figure 1.

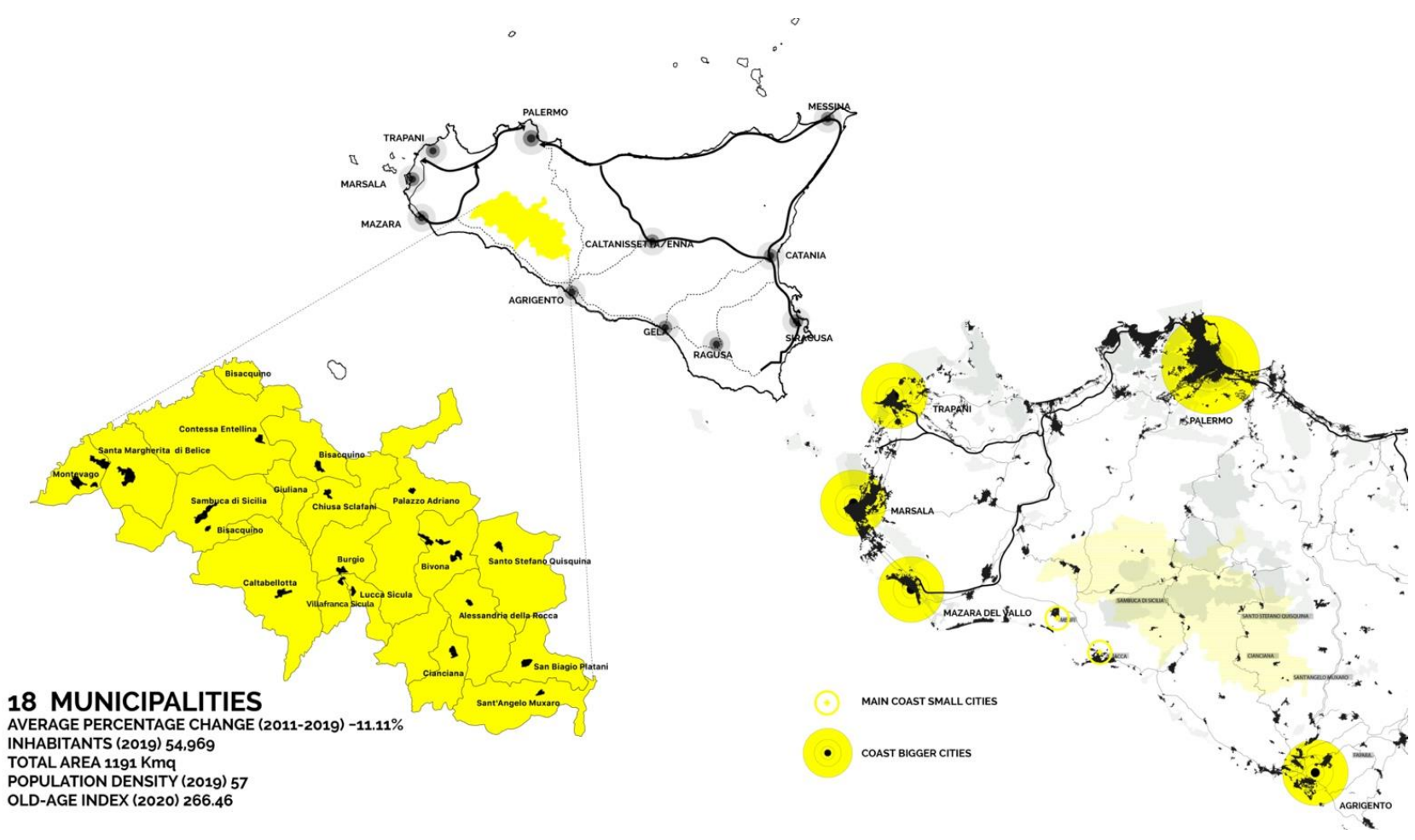

Figure 1. The Sicani Focus Area in Southern Sicily. Data processing (ISTAT, 2020) and graphics: Barbara Lino and Annalisa Contato.

The 18 municipalities of the FA are non-coastal, hilly, or mountainous centres whose territorial surface is spatially contiguous. They are centres with a settled population of less than 7000 inhabitants. In the FA, 13 municipalities fall within the Free Consortium of Agrigento and the remaining 5 within the Metropolitan Area of Palermo (Bisacquino, Chiusa Sclafani, Contessa Entellina, Giuliana, and Palazzo Adriano).

The FA engages with two territorial systems. On the one hand there is the territory of Monti Sicani; on the other hand, there is the Belice Valley and the municipalities affected by the earthquake of 1968.

The area of Sicani is part of a large portion of the regional territory at the margins with respect to the polarisation of the large urban coastal areas (Palermo, Catania, and Messina) that takes its name from the mountain range of Monti Sicani, which was inhabited in prehistoric times by the Sicani people. Contessa Entellina, Santa Margherita Belice, Montevago, and Sambuca di Sicilia, in particular, share with the Valley of Belice the trauma of 14 January 1968, when entire cities were destroyed by the earthquake. During the reconstruction, the national government used two different approaches: Gibellina, Poggioreale, Salaparuta, and Montevago were rebuilt as new cities; the other ten affected cities, including those mentioned falling in the FA, were partially rebuilt with additions to the old destroyed nuclei. 
Observing the FA from the point of view of the SNAI, only 8 of the 12 municipalities in the SNAI Sicani area are included in the FA: those that are coastal or have a strong relation with the coast were excluded in this research.

The total settled population was 54,969 inhabitants (2019) and the average population density was 57 inhabitants per square kilometre compared to the regional average of 192 inhabitants per square kilometre. The 18 municipalities are experiencing progressive depopulation and aging (Table 1). Between 2011 and 2019, the process of population decrease registered a value equal to $-11.11 \%$; the average value of the old age index (2020), equal to 266.46 , highlights how the presence of younger people is weaker (the regional average is 159); in addition, the major part of the municipalities showed a general decrease in the number of births with a birth rate index of -0.99 , compared to -1.4 in the region (Figure 2 ). The structural dependency index, which represents the social and economic burden of the inactive population (0-14 years and over 64 years) on the active population (15-64 years) (higher values show a greater presence of dependent individuals for every 100 working) had an average value in the FA of $62.72 \%$ compared to the regional average of $54.40 \%$.

Table 1. The municipalities of the Focus Area: population statistics. Data processing (ISTAT, 2020): Barbara Lino and Annalisa Contato.

\begin{tabular}{|c|c|c|c|c|c|}
\hline Municipality & $\begin{array}{l}\text { Municipality } \\
\text { Surface }\left(\mathrm{Km}^{2}\right)\end{array}$ & $\begin{array}{c}\text { Population } \\
\text { (31 December 2019) }\end{array}$ & $\begin{array}{c}\text { Population } \\
\text { Density } \\
\text { (31 December 2019) }\end{array}$ & $\begin{array}{c}\Delta \text { of } \\
\text { Depopulation } \\
2011-2019(\%)\end{array}$ & $\begin{array}{r}\text { Old-Age Index } \\
\text { (1 January 2020) }\end{array}$ \\
\hline Bisacquino & 64.97 & 4364 & 67.17 & -11.87 & 249.2 \\
\hline Contessa Entellina & 136.48 & 1658 & 12.15 & -15.62 & 293.6 \\
\hline Palazzo Adriano & 130.10 & 1980 & 15.22 & -14.24 & 322.3 \\
\hline $\begin{array}{c}\text { Santa Margherita } \\
\text { di Belice }\end{array}$ & 67.28 & 6267 & 93.15 & -6.06 & 188.5 \\
\hline Montevago & 32.91 & 2885 & 87.66 & -5.34 & 217.1 \\
\hline Chiusa Sclafani & 57.55 & 2724 & 47.33 & -9.91 & 312.1 \\
\hline Giuliana & 24.14 & 1827 & 75.68 & -14.23 & 367.9 \\
\hline Sambuca di Sicilia & 96.37 & 5736 & 59.52 & -8.21 & 195.7 \\
\hline Burgio & 42.23 & 2616 & 61.95 & -7.07 & 244.6 \\
\hline Bivona & 88.57 & 3475 & 39.23 & -13.73 & 247.8 \\
\hline $\begin{array}{l}\text { Santo Stefano } \\
\text { Quisquina }\end{array}$ & 85.52 & 4386 & 51.29 & -13.20 & 296.9 \\
\hline Caltabellotta & 124.09 & 3477 & 28.02 & -14.29 & 292.5 \\
\hline $\begin{array}{l}\text { Alessandria } \\
\text { della Rocca }\end{array}$ & 62.24 & 2751 & 44.20 & -13.01 & 305 \\
\hline Lucca Sicula & 18.63 & 1758 & 94.36 & -8.36 & 178.4 \\
\hline Villafranca Sicula & 17.63 & 1374 & 77.94 & -4.51 & 181.2 \\
\hline San Biagio Platani & 42.67 & 3102 & 72.70 & -14.35 & 281.7 \\
\hline Cianciana & 38.08 & 3323 & 87.26 & -6.50 & 272.7 \\
\hline $\begin{array}{c}\text { Sant'Angelo } \\
\text { Muxaro }\end{array}$ & 64.52 & 1266 & 19.62 & -19.43 & 349.2 \\
\hline
\end{tabular}




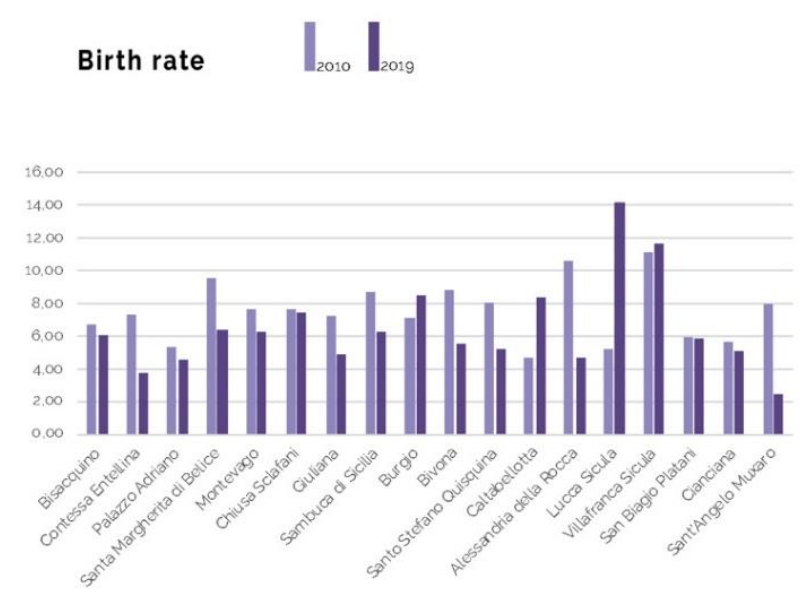

(a)

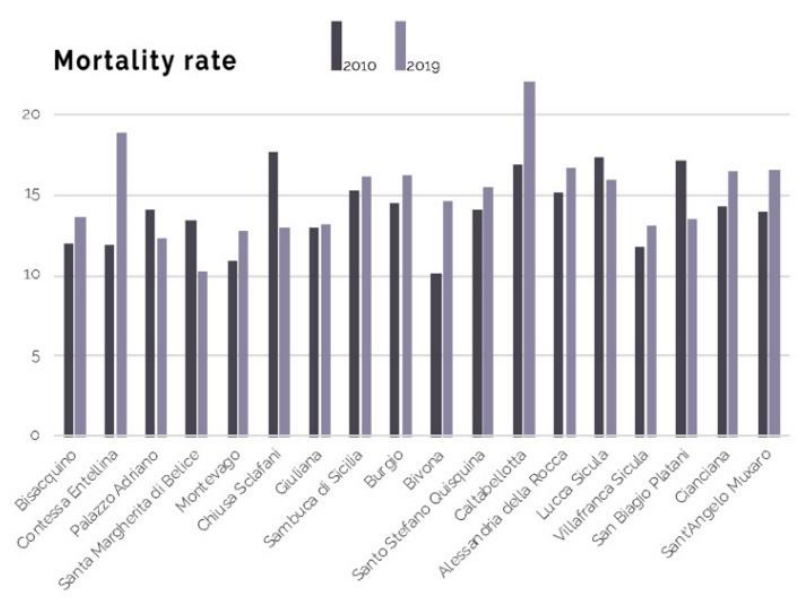

(b)

Figure 2. (a) Evolution of the Focus Area municipalities' birth rate during the period 2010-2019; (b) evolution of the Focus Area municipalities' mortality rate during the period 2010-2019. Data processing (ISTAT, 2020) and graphics: Barbara Lino and Annalisa Contato.

If we look at the variation in the population by age group (Figure 3), we can observe a decrease in all age groups; however, particularly significant is the decrease in the active population groups (15-64 years), which are increasingly forced to move for reasons of work or greater accessibility to basic services.

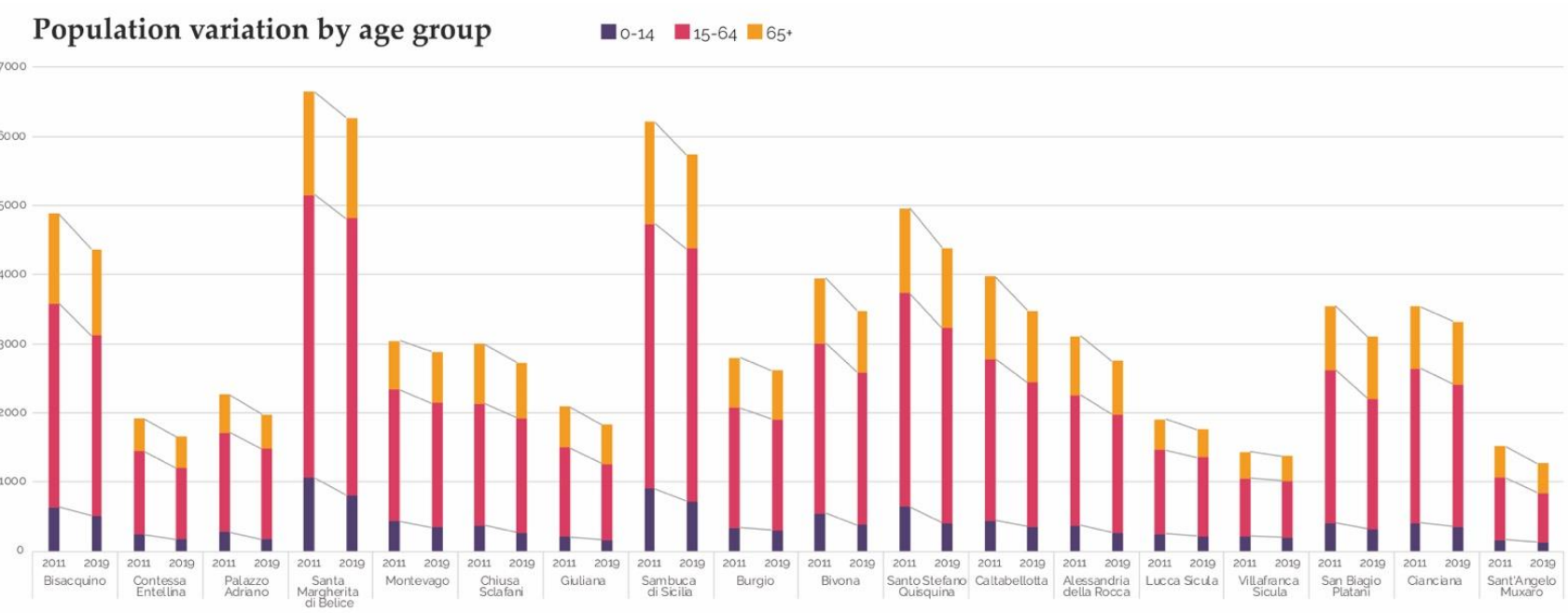

Figure 3. Population variation articulated by age group during the period 2011-2019. Data processing (ISTAT, 2020) and graphics: Barbara Lino and Annalisa Contato.

In addition, the average income per capita in the FA was EUR 12,469 compared to the regional value of EUR 15,846 (2019, Ministero dell'Economia e delle Finanze-Mef) and the average employment rate was $47.55 \%$ (2018) compared to $44.1 \%$ in the Region.

\subsection{The 'Exploration' Phase and the Methodological Structure of the Research Project B4R Branding4Resilience}

The first operative phase of the B4R project is the 'Exploration', a fundamental step towards analysing the territorial contexts (Focus Area) from different points of view, with a focus on spatial interactions. (The B4R project is structured in five phases, corresponding to as many work packages. Two of these phases are continuous during the entire project (Coordination, Communication, and Dissemination), while the other three are the main 
operative phases used to carry out the research project. Each of these phases has the scientific coordination of one of the four Research Units involved. The first phase is 'Exploration', an analytic and mapping phase with the aim to analyse in depth the territorial context being researched. After the analysis and the interpretation of the data and dynamics of the territorial context, each Research Unit select a Focus Area (FA) for intervention towards regeneration. A second operative phase is the 'Co-Design' with communities, with the goal of proposing useful transformations of small infrastructures in the selected villages. The third phase is the development of "Co-Visioning" processes in collaboration with local actors.)

The Exploration phase's aim is to bring out networks, multi-scalar interactions, and intersections between territories and material and immaterial resources. For this phase, qualitative and quantitative tools are being defined with the aim to analyse each territory not only in its spatial dimensions, but also in its immaterial dimensions, such as formal and informal relationships, community identities, traditions, people, and the creativity of bottom-up initiatives. To this end, projects, policies, and benchmark contexts are investigated; public and private actors and stakeholders are mapped; and quantitative and qualitative data are collated and analysed for the production of maps.

The Exploration phase is conducted by the following main steps:

Quali-quantitative analysis and mapping

- Definition of a set of topics and indicators;

- Recognition of quantitative and qualitative data;

- A mapping phase based on a main quantitative approach and field research.

Stakeholder analysis and interviews

- $\quad$ Stakeholder analysis based on a qualitative approach using stakeholder lists and matrixes, interviews with key stakeholders, and discourse analysis (simultaneously with the previous steps);

- $\quad$ Stakeholder interviews.

In line with the B4R research methodological framework, in this paper we critically describe some of the results of the Exploration phase in the Sicani FA conducted by the Research Unit of Palermo.

We analyse the most relevant outcomes of the mapping in terms of potentials and critical aspects, with some thematic focuses chosen according to their relevance to the specificities of the Sicilian case study.

For the stakeholder analysis and interviews we present a synthesis of the main results.

\subsubsection{Quali/Quantitative Analysis and Mapping Methodology: The Four 'Dimensions'}

The first part of the Exploration phase was the definition of a set of topics and indicators to guide and coordinate all research units of the project in a clear methodological framework. The data/indicators identified and the interpretative maps generated by an integrated reading constitute the common starting point for the exploration of the four FAs of the B4R project (Marche, Piemonte, Trentino, and Sicily).

For processing the data needed to develop simple and complex indicators, national and regional institutional databases have been used, as well as, in some cases, fieldwork and the subsequent georeferencing of the data. All the maps are geographical information system based.

With the aim of having a reading of the territory able to describe its different components, the maps are articulated on the basis of the identification of four survey 'dimensions':

1. Dimension 1: Infrastructures, Landscape, and Ecosystems

2. Dimension 2: Built and Cultural Heritage, Settlement Dynamics

3. Dimension 3: Economies and Values

4. Dimension 4: Networks and Services, Community and Governance Models.

Each dimension is articulated in the main maps, schemes, and graphics, which represent data and indicators according to their theme, and a 'transversal' indicator is chosen 
based on its significance and as an element of interaction with dimensions and other different themes.

\subsubsection{Stakeholder Analysis and Interview Methodology}

Stakeholders are the people who have a specific interest in a certain topic or a decision to adopt a public policy. As pointed out elsewhere [18], their involvement is essential in the formulation and implementation of effective public policies. They can be individuals, organisations, associations, or even groups of people, whose action (and/or attitude) is able to produce some effects on the process of achieving policy objectives. We will therefore have specific kinds of stakeholders, depending on the types of intervention in a specific selected area that the policy intends to impact. In some cases, the way in which the use of the spaces by the resident citizens is declined may highlight or reactivate conflicting positions between different people. Generally, different broad categories of stakeholders can be classified. Among these, there are public institutions, including organised and nonorganised groups. The selection of the appropriate group for each kind of policy, however, descends both from a precise analysis of the context and an examination of the various interests at stake. This kind of study makes it possible to carry out a fruitful mapping of stakeholders and to decide which of them should be involved, as well as when and how. However, a number of caveats need to be contemplated. From this perspective, it is necessary to define their size, degree of representativeness, availability of resources, skills, and knowledge, as well as their location. These factors are also useful to establish the degrees of influence of stakeholders, even in the implementation process of a public policy. On the other hand, in order to establish their level of interest, it is necessary to assess the type of policy and the potential actions of these groups of people to express their own interests and promote their participation in the decision-making process (For interesting further reading consider: Gomes, R. [2004]; Mitchell, R.K., Agle, B.R. e Wood, D.J. [1997]; Winstanley, D., Sorabji, D. e Dawson, S. [1995]) [19-21]. Considering the need to identify the stakeholders present in the area under analysis and the different perspectives of the stakeholders, it is also necessary to highlight the decisions taken with regard to the way in which the empirical base was constructed.

In a first, explorative phase of the field research, various contacts with several stakeholders were conducted. Following the first findings, the key stakeholders were selected and interviewed. In particular, ten interviews are discussed here, involving local policymakers, actors from the real estate market and the tourism sector, cultural associations, and private individuals. They are presented and discussed in order to provide a picture of the limits and potentials of the territory as perceived by these different actors. Among private individuals, some foreign inhabitants who bought properties in the Focus Area were interviewed. These people who bought houses in the territory of Sambuca di Sicilia and Cianciana are considered a specific category of local actors. Their trajectories, practices, and discourses were analysed as well. Given the small number, the interviews have to be considered as the testimonies of 'privileged actors': those subjects who, by condition or experience, can be considered 'significant sources' or 'key witnesses' [22] (p. 55). Given the heterogeneity of the subjects, it was appropriate to use semi-structured interviews, where the researcher proposes general arguments according to the research objectives 'and then leaves to the interviewee the complete management of the treatment of them' [22] (p. 53).

The interviews were analysed following a qualitative approach. The quantity of data available and the heterogeneity of the subjects does not allow the use of other instruments, which are considered superfluous and not well aligned to the objectives of the research.

Regarding the new inhabitants, the analysis of the interviews relied on discourse analysis, a strategy of research grounded in the pioneering studies of Michel Foucault [23,24] that has been employed in many ways by the social sciences. Discourse analysis 'is a heterogeneous family of (mainly) qualitative interdisciplinary research approaches concerned with studying the use of language' [25] (p. 215). It is a multidisciplinary approach to research 
revealing the processes underlying the formation of texts: it evaluates how discourses are constituted, producing a particular knowledge of the world.

\section{Results}

Based on the indicators defined by the Research Group of B4R, the exploration phase was characterised by in-depth research of the information needed to draw up maps of the territory expressing its peculiar characteristics, broken down by the previously defined dimensions.

The mapping process aimed to highlighting both the criticalities of the Focus Area, but also its potentialities from the point of view of existing resources and innovative bottomup processes that are being implemented, as well as its ability to network through the activation of different territorial development policies.

The exploration and mapping phase showed a territory with a wide endowment of resources and widespread vivacity of projects but marginal and indeed fragile conditions (environmental, socio-economic, and demographic).

The description of the results obtained for each of the four dimensions of analysis, which interact with each other, was the starting point for the subsequent phases of the project, enabling the identification of critical points/weaknesses and resources/potentialities.

\subsection{Dimension 1: Infrastructures, Landscape, and Ecosystems}

The Focus Area is a hilly territory with a mountainous area, with peaks over $1000 \mathrm{~m}$, culminating in Rocca Busambra and Monte Cammarata, both over $1500 \mathrm{~m}$ above sea level.

It is characterised by important resources from a naturalistic and landscape point of view. There are important watercourses, such as the Platani River, the Sosio-Verdura River, and the Frattina-Belice Left River, and the richness of the territory from the water point of view is also characterised by the presence of several thermal springs, which express the potential of this territory also from a tourist-receptive use linked to health and well-being. The land use reveals the important ecological and environmental value of the natural areas and the high landscape biodiversity of the FA.

There are also several nature reserves (Such as: 'Monti di Palazzo Adriano e Valle del Sosio' (almost 6000 hectares), 'Monte Cammarata' (about 2000 hectares), and the 'Riserva Naturale Orientata di Monte Genuardo e Santa Maria del Bosco' (more than 2500 hectares), managed by the Azienda Foreste Demaniali of the Regione Siciliana) and numerous sites of community importance (SIC) and a vast special protection area (ZPS), as shown in Figure 4.

The Accessibility of the Sicani Area

In line with the National Strategy for Inner Areas, the Focus Area was analysed also in its infrastructural dimension to understand its peripheral and marginal factors with respect to the main urban poles.

From the point of view of its accessibility, the FA shows evident criticalities that concern all 18 municipalities in different ways. The area is connected to the nearest urban poles (Agrigento, Palermo, and Castelvetrano) through the State Roads 118 and 624 that cross the territory from north to south and from east to west. The A29 motorway, in spite of its proximity to the western municipalities of the FA, does not serve any municipality, with the result that the average travel time to reach Palermo, the Sicily's capital, by private vehicle is about $1: 50 \mathrm{~h}$ (with peaks of 2:40 $\mathrm{h}$ from the municipalities closest to Agrigento) and about 1:20 $\mathrm{h}$ to reach Agrigento (with peaks of $2 \mathrm{~h}$ from the municipalities closest to Castelvetrano) as in Figure 5a,b. The two airports, Birgi and Falcone-Borsellino, are on average $2 \mathrm{~h}$ away from the FA, with times that reach $3 \mathrm{~h}$ for the municipalities near Agrigento. In addition to road travel times, critical issues also concern rail transport. A vast network of narrow-gauge railways that ran through the territory has now been completely decommissioned, with the result that no municipality in the FA has an active railway stop. Public transport connections are also poorly served with a low frequency of local public transport services to the urban centres. 


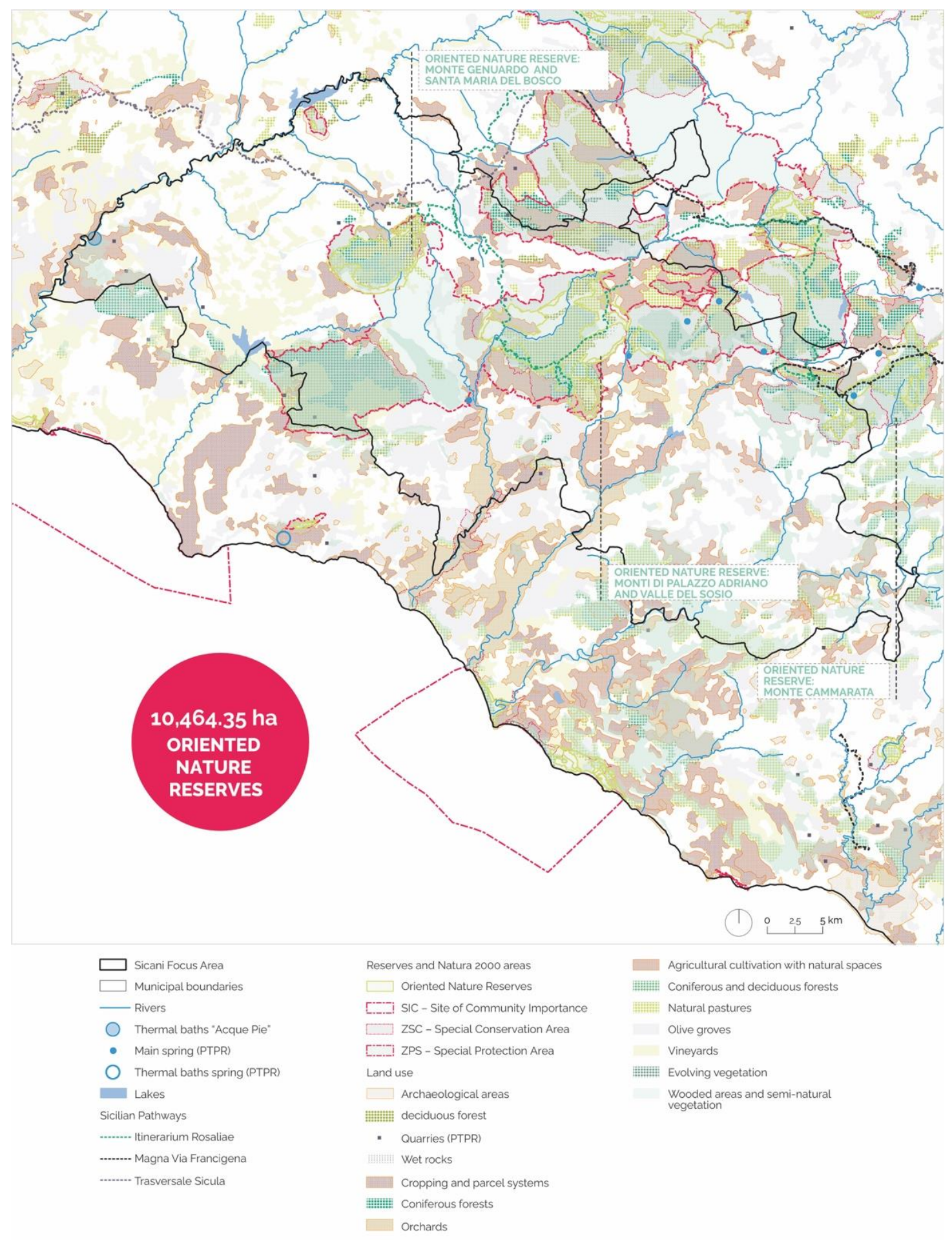

Figure 4. Natural and Landscape Heritage of the Sicani Focus Area. Data processing and graphics: Barbara Lino and Annalisa Contato. Data sources: CTR Regionale Sicilia (1999), Linee guida del Piano Paesaggistico Regionale (PTPR) (1999) Sicilia, Sistema Informativo Territoriale Regionale Sicilia, TINITALY, Copernicus-CORINE Land Cover (2018). 
Accessibility to the Focus Area from Agrigento

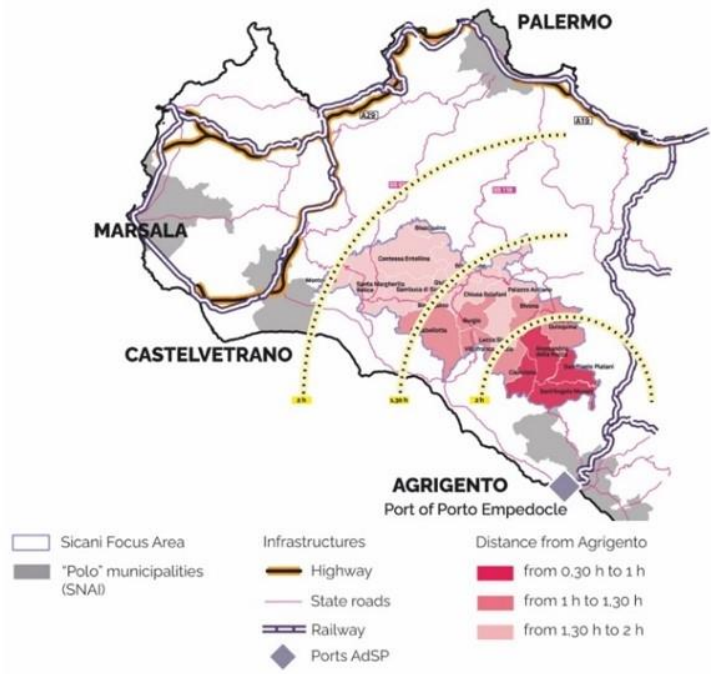

(a)

Outflows from the Focus Area

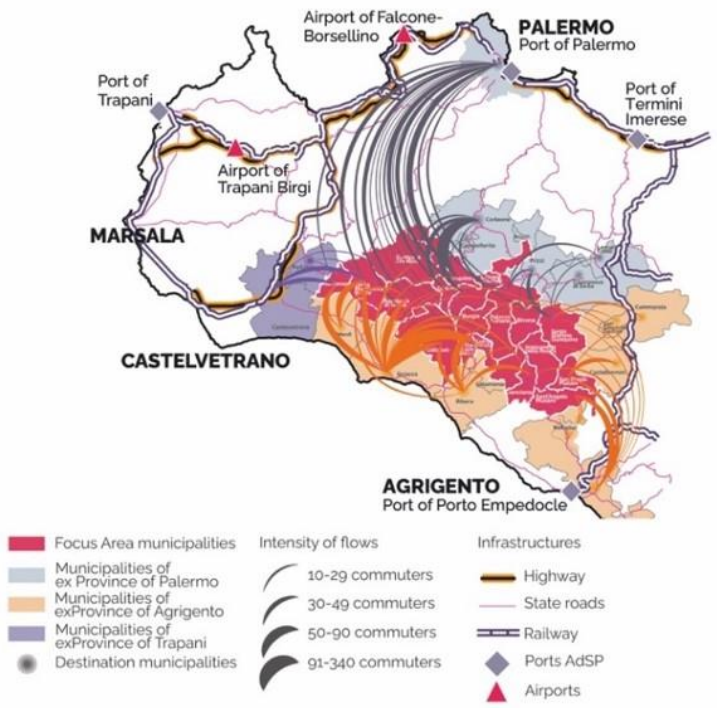

(c)

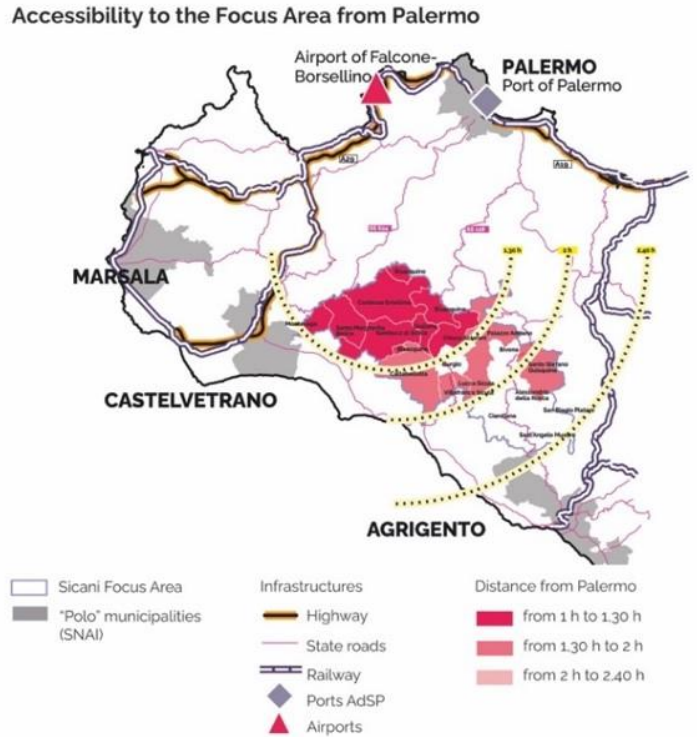

(b)

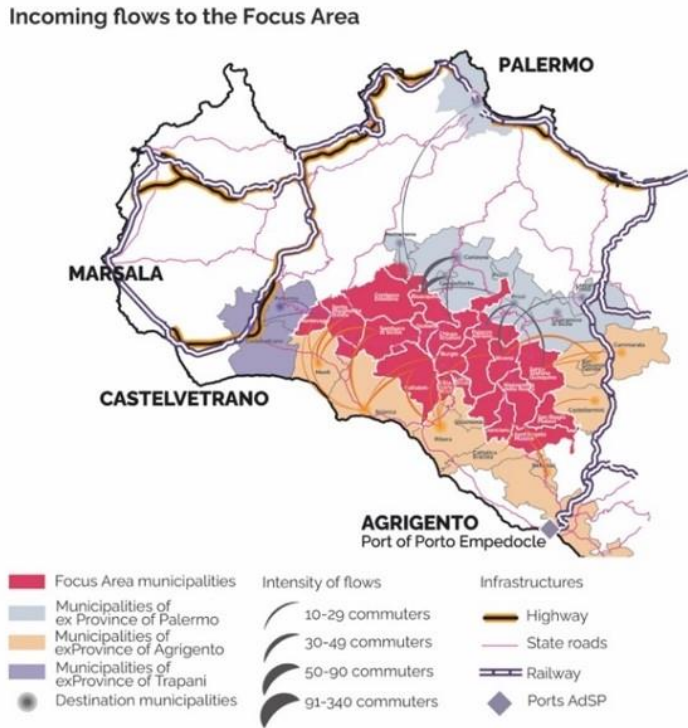

(d)

Figure 5. (a,b) Accessibility to the Focus Area from the main urban centres; (c,d) The movement of commuters for study and work inside and outside the Focus Area. Data processing (ViaMichelin, 2021 and ISTAT, 2011) and graphics: Barbara Lino and Annalisa Contato.

The movement of commuters for study and work purposes inside and outside the Focus Area contribute to defining the existing relations between the area and the surrounding territory, highlighting the main interdependencies and the main places of attraction, as shown in Figure $5 \mathrm{c}$, d. At first glance, one can notice a clear difference in quantity between incoming and outgoing flows, a factor that shows a low attractiveness of the area both in the work and in the education fields. Further analysing the quantity and thickness of the flows, it is possible note a strong link between the municipalities of the Focus Area and the poles of Palermo and Agrigento, as well as with some peripheral centres, such as Sciacca, Ribera, and Corleone, adjacent to the borders of the FA. On the other hand, the relationship with the Belice territory is scarce, except for a few movement flows, both incoming and outgoing, of the FA municipalities close to that area (Montevago, Santa Margherita del Belice, and Sambuca di Sicilia). 


\subsection{Dimension 2: Built and Cultural Heritage, Settlement Dynamics}

The Focus Area is characterised by an unspoilt rural landscape, archaeological sites that are far from the traditional tourist circuits, and a precious historical heritage shown in Figure 6.

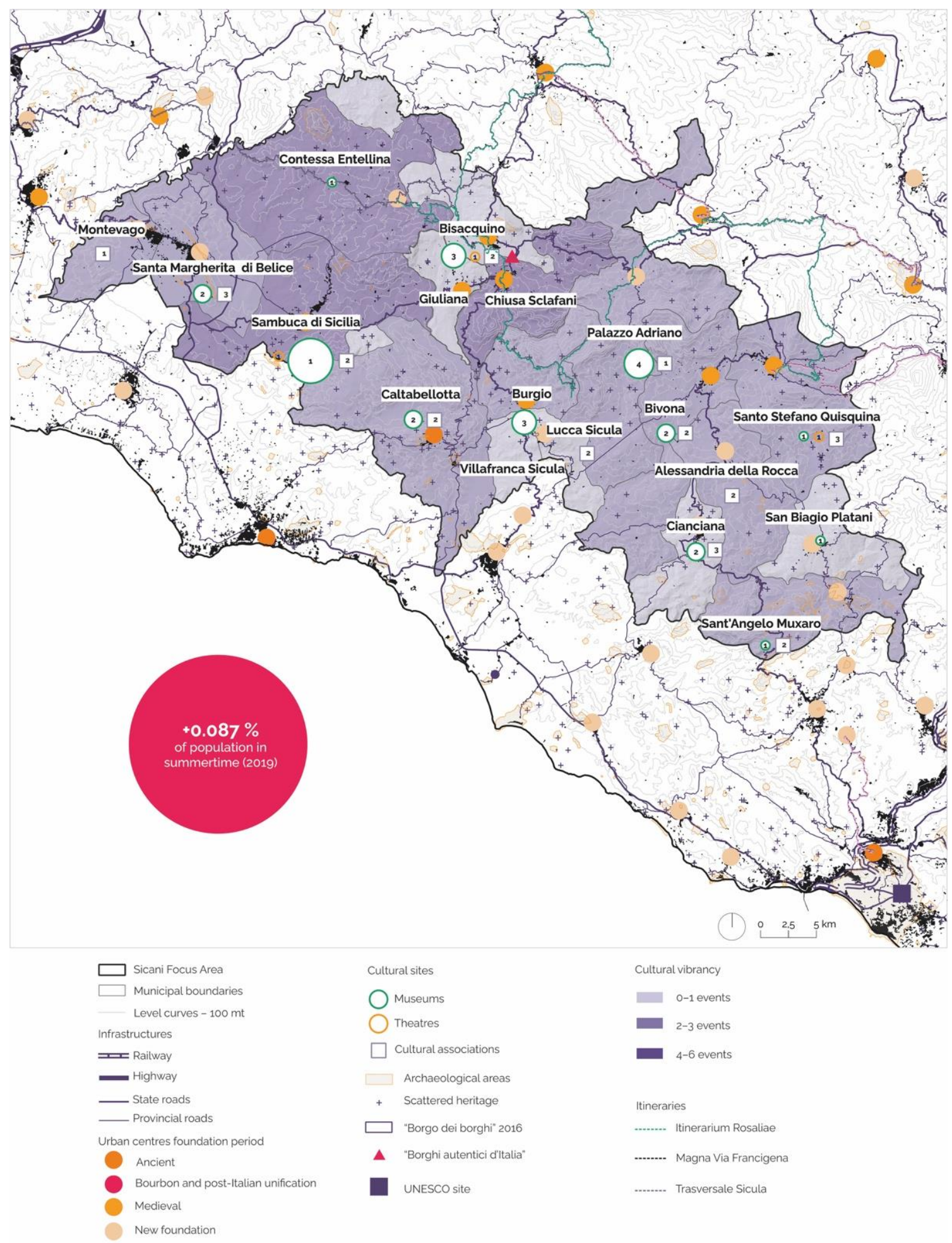

Figure 6. Networks, places and cultural activities. Data processing and graphics: Barbara Lino and Annalisa Contato. Data sources: CTR Regionale Sicilia (1999), Linee guida del Piano Paesaggistico Regionale (PTPR) (1999) Sicilia, Sistema Informativo Territoriale Regionale Sicilia (2021), CopernicusCORINE Land Cover (2018), ISTAT (2020), on field research. 
The settlement structure is characterised by an archipelago of small urban centres (with a discontinuous and sparse pattern) and rural villages.

In the area there is 1 historical centre of ancient origin (Caltabellotta), 7 historical centres of medieval origin (Bisacquino, Bivona, Burgio, Chiusa Sclafani, Giuliana, Sambuca di Sicilia, and Santo Stefano Quisquina), and 10 newly founded historical centres (Alessandria della Rocca, Cianciana, Contessa Entellina, Lucca Sicula, Montevago, Palazzo Adriano, Santa Margherita di Belice, San Biagio Platani, Sant'Angelo Muxaro, and Villafranca Sicula), established following licenziae polulandi.

Both the historical permanence of the ancient settlements and the numerous archaeological sites and assets contribute to defining the area's identity.

From a cultural point of view, the FA has a stratified system of resources, cultural services, and human capital engaged, through trade associations, in the promotion and enhancement of the territory. In Sant'Angelo Muxaro, in the 20th century Paolo Orsi discovered a group of large tholos tombs whose rich furnishings are linked to King Kokalos (the best-known Sicani king), a discovery that led to the site being considered one of the most important in proto-historic Sicily. The summit of Mount Adranon hosts the remains of an ancient city named Adranon. This ancient city, a Greek-Punic settlement, was destroyed around the 3rd century BC (according to archaeological excavations). The imposing ruins, estimated to date from the 8th to 3rd century BC, reveal the strategic importance of the centre from the earliest archaic phase, as they dominated the road connecting Selinunte with Akragas. It is believed that it was a stronghold of the defence system built by the Carthaginians. The itinerary of the Magna via Francigena and the Itinerarium Rosaliae are important routes for tourism in the area.

In the area there are 159 assets scattered among buildings of military, religious, residential, and productive architecture (Regione Siciliana, 1999), while as regards the network of related services, there are 30 museums throughout the FA.

Cultural events play an important role in keeping the area alive in terms of its culture and identity. The main purpose of these events is to highlight the identity characteristics of the sites, excellent products, and natural beauty and to promote art. They are mainly concentrated in the spring and summer months, but there is no significant change in the resident population in this period.

This territory, in fact, is rich in the production of typical products of excellence, there are two slow food presidia, and quality craftsmanship is preserved (such as the traditional and well-known local pottery in Burgio, 'City of Ceramics'; the tradition of the straw chair in Bivona; and the tradition of crochet and wickerwork in Villafranca Sicula).

The richness of the villages in these territories has also received national recognition, such as the title of 'Borgo dei borghi' awarded to Sambuca di Sicilia in 2016 and the title of 'Borgo autentico d'Italia' awarded to Bisacquino.

\subsubsection{Mapping of Hidden Resources}

The Sicani territorial palimpsest consists of natural and anthropogenic traces overlapped in a complex stratification, where isolated fragments and residual scraps speak of disappeared activities and transformed societies. Not entirely lost, the elements are a result of relationships between legal and illegal uses, shapes and memories: among these are assets confiscated from organized crime; mines; and disused railways. Each episode evokes a broader constellation that exploration and mapping activities help to reveal.

Confiscated farms, buildings, and land punctuate the FA as symbols of a social redemption. The report of the National Agency for the Administration and Destination of Assets Seized and Confiscated from Organized Crime (ANBSC) stated that for the two-year period 2019-2020 34.46\% of the confiscated assets are in Sicily, with a total of 5677. The data about the FA, as shown in Figure 7 (88 total confiscated properties, of which 42 are properties; 27 are properties under management; 5 are companies; and 14 are companies under management-as of 4 January 2021), document the public acquisition of land and properties that can be reused by replacing the illicit interests of individuals with the con- 
struction of common goods and solidarity networks, with social objectives. As indicated by the 'Guidelines for the administration aimed at the destination of seized and confiscated properties' (September 2019), the priorities are improving the knowledge of the confiscated assets as well as the opportunities to design concrete possibilities for their reuse. The numbers can be translated into spaces (from the cadastral maps it is possible to trace the buildings and land) to which new meanings and functional programs can be attributed.

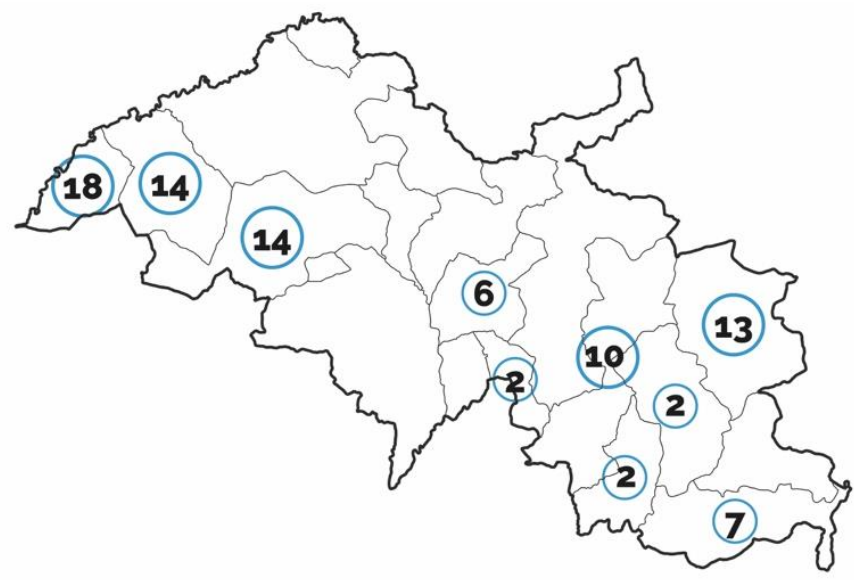

Figure 7. Confiscated and state properties. Data processing and graphics: Luciana Macaluso. Data source: www.benisequestraticonfiscati.it (accessed on 3 January 2022).

Different to confiscated assets, disused quarries and mines (Figure 8) and railways (Figure 9) are recognisable territorial infrastructures. They became part of the collective memory, that is, something more than what they were used for, mirroring a society, and, in their mutation into ruins, being the expression of an aesthetic value.

In the FA, the railway made rural zones accessible by connecting them to coastal centres, improving the organization of the sulphur market. The construction of mines and railways transformed the agricultural hinterland, revealing its qualities and places hitherto unknown. An unprecedented study of the territory (altimetric surveys, geological surveys, surveys of water networks, and botanical investigations) optimised the production of the mines and ensured an appropriate relationship between the soil, tracks, and locomotives. The FA intercepts some of the 'sulphur mines [...] on the line that connects Etna to Cattolica Eraclea and which, in its geological conformation, reaches the point where, in 1831, the Ferdinandea island was built' [26] (p. 91). Overall, the south-eastern part of the FA was mainly subject to mining [27]; the abandoned mines (including, in the municipalities of Alessandria della Rocca, Bivona, Cianciana, and Sant'Angelo Muxaro: Alessandria della Rocca-Solfara Cinié (active in 1839); Bivona, locality Balata-Solfara Balata (active in 1839); Cianciana-Solfara Cappadone; Cappadone, near Cianciana, in the locality of Falconera; Grotticelli, north-west of Cianciana; Grotticelli, north-east of Cianciana; Guidi, near Cianciana, in the locality of Raddoli; Falconera, north-east of Cianciana; Mormino, near Cianciana, in the locality of Raddoli; Passarello, north-east of Cianciana; Passo di Sciacca, north-west of Cianciana; Polizzi, near Cianciana; Tamburello, near Cianciana, in the locality of Raddoli; Lamela, near Sant'Angelo Muxaro; and Mizzaro, near Sant'Angelo Muxaro) were once again annexed to the agricultural plot. Literature depicted mining as socially backward and unfair (from Sciascia, to Verga and Pirandello), while these picturesque ruins 
step by step came back to a natural state, disappearing from everyday collective life. In fact, the reasons to arrive or cross these remote places progressively ceased. People remember mines as an economic engine of the past. However, the relics could again contribute to an economic, spatial, and social recovery. Once again, local inhabitants-like their predecessors who left the rural land and farms to become miners-should push towards another development. In the Ruhr region of Germany the soil was destroyed and the vegetation was damaged. The mining use left pits, holes, mounds of debris, acid residues, sludge, and the danger of landslides. That condition led on one side to a new contemporary naturalisation of the sites, and on the other to their conversion into a museum. It could be considered that the history of the Ruhr Museum, already begun in 1901, was mainly operated by the historical association for the city and monastery of Essen (later converging in the Folkwang Museum) and the Krupp educational association [28]. Differently, the FA is in the more inner and peripherical part of Sicily, where just in more recent times activists joined in to slowly envisage a possible change, also considering German best practices. In 2020 the Ruhr Museum at Zollverein (a UNESCO site in Essen) celebrated 'Ten to Ten': ten years after the opening of the cultural capital RUHR.2010 and the new museum. Mining towers and silos, and some still industrial parts characterise the Ruhr skyline. Between the buildings, dense vegetation made the heavy environmental pollution appear far away. Some of the underground tunnels can be visited. In a sustainable action considering the climate change, more appropriate cultivation should also be proposed in Sicily, where historically rural lands prevail over the woods, and recently tropical fruit species are increasingly being successfully grown [29].

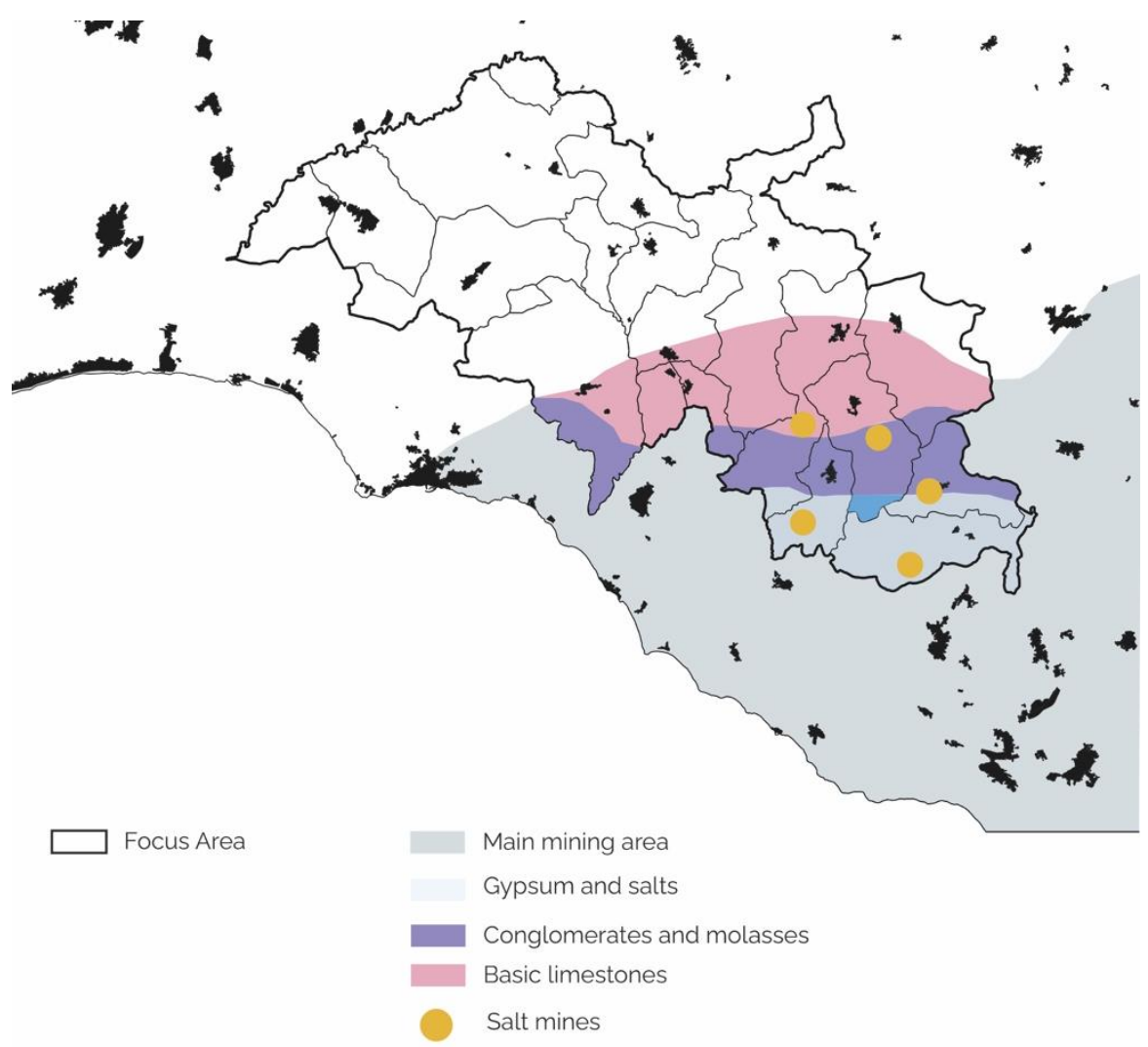

Figure 8. Quarries and mines. Data processing and graphics: Luciana Macaluso. 


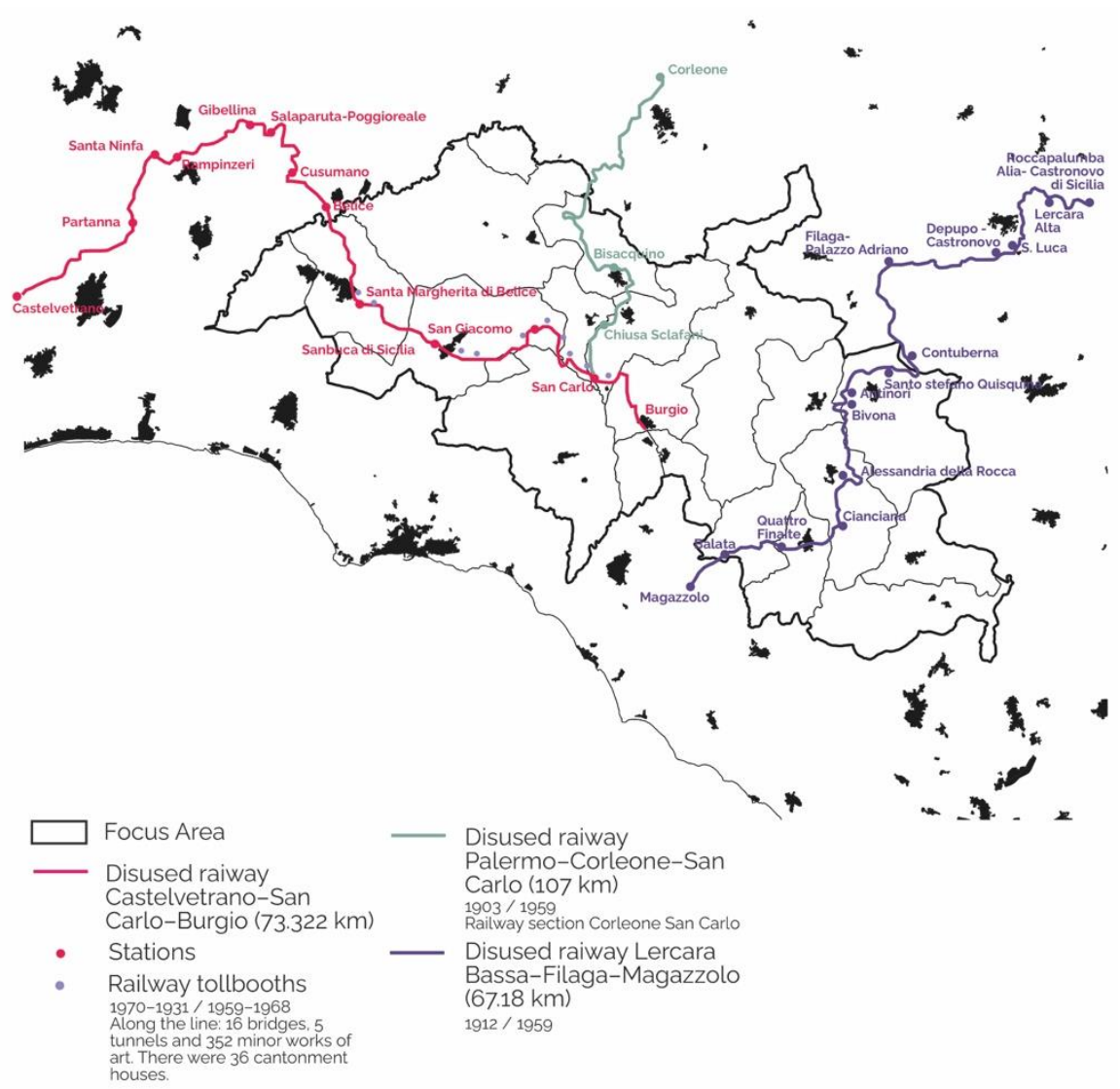

Figure 9. Disused railway lines. Data processing and graphics: Luciana Macaluso. Data source: www.ferrovieabbandonate.it (accessed on 3 January 2022).

Recycling and adaptation concern, at the same time, the different components of the territory that interact in the landscape. Among them, the FA includes a lot of abandoned railway, which entered the collective memory firstly as democratic and experiential means by offering the ideal conditions to enjoy the landscape also, unconsciously, while the miners were on the way to work. The train frees travellers from the fatigue of moving from one place to another, allowing the perception of a landscape dimension, yesterday as today, when a new awareness of the environmental heritage has certainly been acquired. In a continuous movement, artefacts, vegetation, light, and colours are mixed with your own face reflected on the window. Michael Jakob's formula P $=\mathrm{S}+\mathrm{N}$ [30] (p. 30) which links the landscape $(\mathrm{P})$ to the contact $(+)$ between subject $(\mathrm{S})$ and nature $(\mathrm{N})$ is perfectly expressed in this condition.

The FA includes more than $100 \mathrm{~km}$ of disused railway routes classed under three lines:

1. The Palermo-Corleone-San Carlo line was built beginning in 1884 and closed in 1959 In 1898, the Sicilian Society for Economic Railways (SSFE) obtained the concession for the construction and operation of the Corleone-San Carlo and in 1903 the connection between Corleone and San Carlo station was inaugurated. When Ferrovie dello Stato acquired the line, the terminus was moved to Burgio. In 1928, the connecting section with the line between Castelvetrano, San Carlo, and Sambuca di Sicilia was inaugurated. Until 1953, the train to Corleone and San Carlo left from Palermo Sant'Erasmo station, and for a long period it was the most popular way to connect the capital with the area of the interior. In the summer of 1953, the terminus was moved back to Acqua dei Corsari (see the database ferrovieabbandonate.it, accessed on 3 January 2022). From Godrano to San Carlo (about $70 \mathrm{~km}$ ), today a bicycle lane connects interesting natural areas (Ficuzza, Drago Gorge, and Rocca Busambra). 
2. The Castelvetrano-San Carlo-Burgio railway (stopping at S. Carlo, S. Giacomo di Sicilia, Sambuca di Sicilia, S. Margherita Belice, Belice, Cusumano, SalaparutaPoggioreale, Gibellina, Rampinzeri, S. Ninfa, and Partanna, Castelvetrano. (See: database ferrovieabbandonate.it)) was built between 1910 and 1931 and definitively abolished between 1961 (Salaparuta-San Carlo section) and 1972 (the CastelvetranoSalaparuta stretch) after the Belice earthquake of 1968. Currently this railway site is visible for almost the entire extension, and is generally used as a country road or for walks in the landscape [31] (p. 24) In the Santa Margherita Belice-Salaparuta section the expressway Palermo-Sciacca overlapped it. Between Partanna and Castelvetrano the route is not recognizable. Most of the railway's service buildings are in a fairly good state of conservation, but the bridge over the Belice partially collapsed. The buildings of the former stations and services are generally abandoned. The former stations of Sambuca di Sicilia, Salaparuta, and Gibellina disappeared (see the database ferrovieabbandonate.it, accessed on 3 January 2022).

3. The Lercara Bassa-Filaga-Magazzolo railway was built between 1912 and 1924 (stopping at Lercara Bassa, Lercara Alta, S. Luca, Depupo-Castronovo, Filaga, S. Stefano Quisquina, Antinori, Bivona, Alessandria della Rocca, Cianciana, Quattro Finaite, Balata, and Magazzolo. The service buildings are generally abandoned and often in ruins (see the database ferrovieabbandonate.it, accessed on 3 January 2022)). It can only be traced in parts, often as a country road; some stretches are included in cultivated fields or became local roads. The Cianciana-Magazzolo section has been transformed into a provincial road.

The decommissioning of the railway coincided with the closure of the mining activities, as the main reason for its construction vanished. Some parts of the railway have been converted into cycle and pedestrian paths, and some mines have been subjected to protection, showing a different interest of the communities. Now, landscape and architectural design should contribute to enhance the quality and use of these places, as for example 3sstudio and Voarino Cairo Associati showed in the reuse of the railway line Albisola Superiore-Celle Ligure (Savona, Italy) spending about EUR 350 per square meter [32] or in the general case of the Spanish 'Vias Verdes' [33].

Will residual signs be absorbed into the oblivion of the silent places to which they belong? The B4R research documents that where apparently nothing seems to happen, in the internal territories of southern Sicily, new experiential (tourist, artistic, didactic, etc.) practices and housing (artist residences, temporary apartments, etc.) are slowly developing. These processes envisage new re-compositions of the available objets trouvé, recovering memories and fantasies in a 'post-production' [34] (p. 98) where what is in the place can be collected and reorganized, even in a temporary and fragile way, in order to take an advantage.

\subsubsection{Mapping Tourism}

A boost for to the economic and social development of the territories of the FA may derive from tourism, which in the last decade experienced a growth on the island of Sicily. It is thus important to quantify the degree of the development of tourism activity in the FA. However, whereas it is relatively simple to provide a definition of tourism-by considering, for example, the definition provided by the UNWTO [35] - defining, and so mapping, the tourism industry, or tourism industries [36], is not so simple as one might initially think. This because, whereas by tradition industries are defined in terms of their products, in the case of tourism any product and service which facilitates travel activity away from one's usual environment may be considered as part of the tourism industry [37]. However, a challenge to this approach is that enterprises which produce commodities for tourists, of course, may serve also non-tourists. Consequently, a prevalence approach, based on the relevance of revenues from tourism, is generally adopted. Bearing in mind these difficulties, in what it follows, traditional tourism statistics are considered, such as accommodation statistics, including the number of establishments, arrivals, and presences, and derived indicators. Moreover, in addition to considering these aggregates, other limitations-related 
for example to same-day travellers; multi-destination trip behaviour [38]; the unavailability of detailed information at a detailed territorial level, such as the municipality; and, more generally, issues linked with the so-called unobserved tourism [39]—should be taken into account.

At the municipality level, the Italian National Institute of Statistics (ISTAT) provides information on the number of accommodation establishments and on the related numbers of bed places, by category. Figures 10 and 11 report respectively the yearly values of the number of establishments and number of bed places for the set of 18 municipalities in the FA from 2002 until 2019. A strong increase in the trend in the number of establishments may be observed in the FA, especially regarding other types of collective accommodation establishments category. These include bed and breakfast, rented apartments, agritourism farms, and other types of collective establishments (e.g., campsites). In terms of composition, a prevalence of other types of collective accommodation establishments characterizes the study area, with more than 40 non-hotel accommodation establishments compared to 7 hotels and similar establishments in 2019. Despite being of much smaller size, with an average number of beds per establishment equal to 7.5, compared to an average of 33.7 for hotel and similar establishments, the other types of collective accommodation establishments category offers a number of beds which is about 1.4 times higher those available in hotel and similar establishments category.

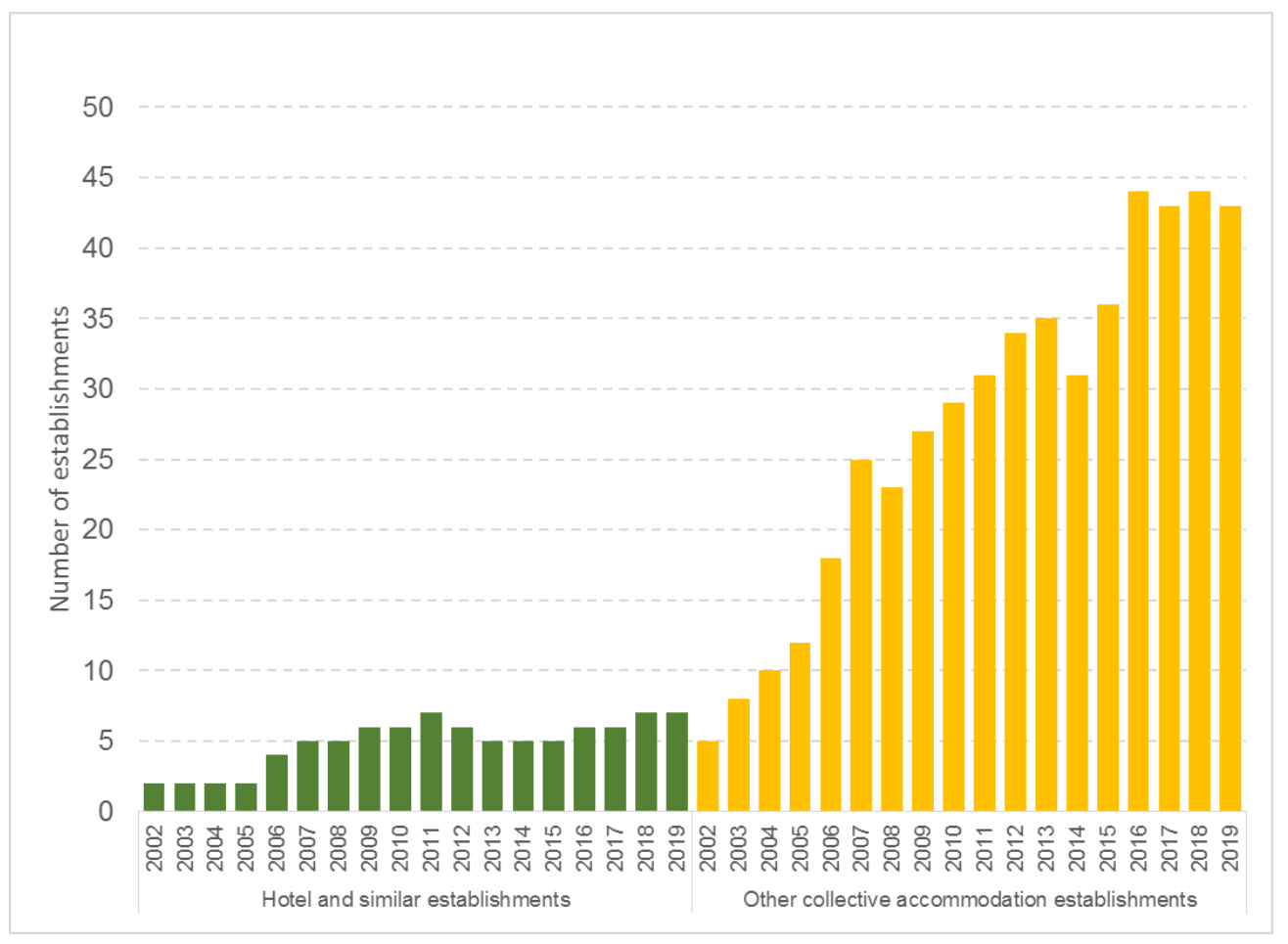

Figure 10. Number of establishments by category in the 18 municipalities of the study area, years 2002-2019. Data processing (ISTAT, 2020) and graphics: Mauro Ferrante. 


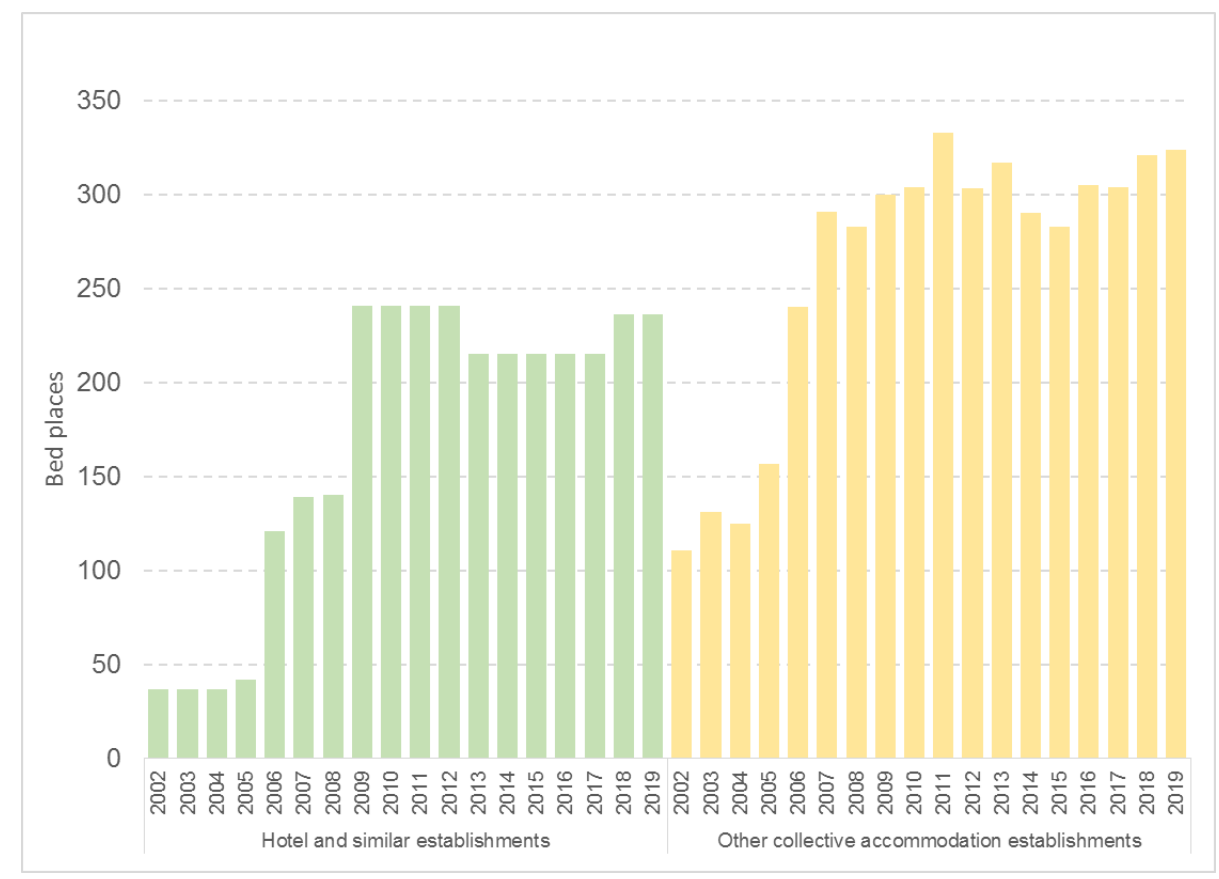

Figure 11. Number of bed places by establishments category in the 18 municipalities of the study area, years 2002-2019. Data processing (ISTAT, 2020) and graphics: Mauro Ferrante.

In Figures 12 and 13 the distribution of the number of hotel and similar establishments and other types of collective accommodation establishments, respectively, are reported. A high degree of concentration of hotel establishments appears, with only 4 out of 18 municipalities of the study area containing at least one hotel. Much better distributed among the municipalities of the study area are the other types of collective accommodations, with only four municipalities without any type of establishment.

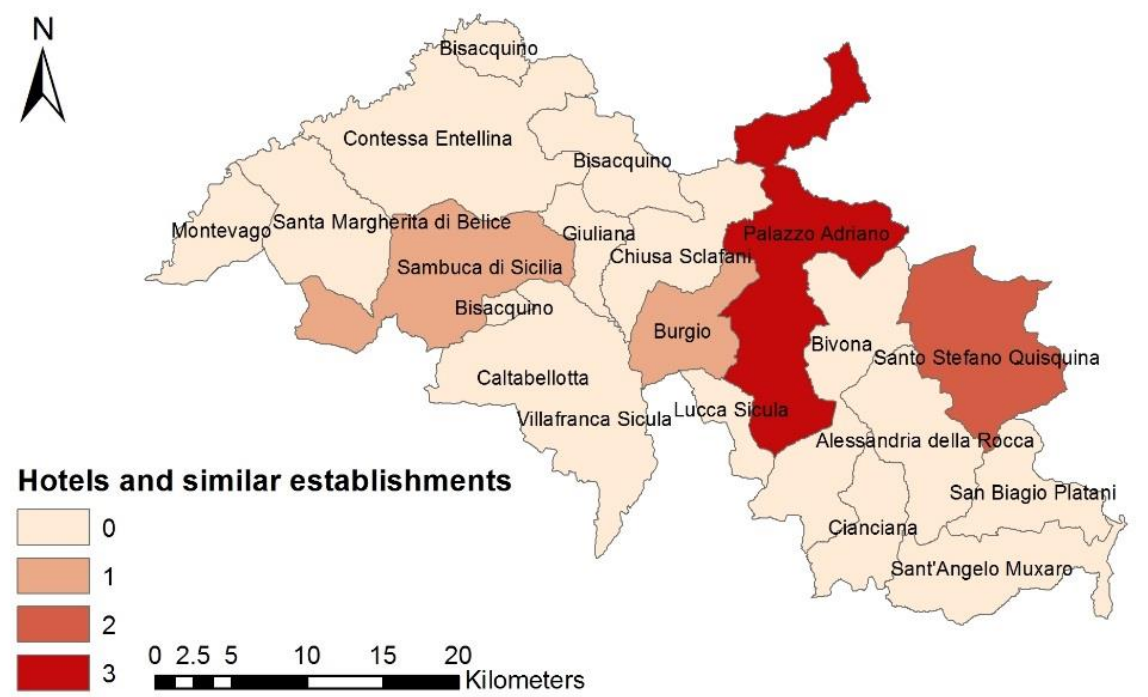

Figure 12. Number of hotels and similar establishments by municipality, year 2019. Data processing: Osservatorio Turistico-Geoportale Sicilia-del dip. Turismo, Sport e Spettacolo-Regione Siciliana (2019). Graphics: Mauro Ferrante. 


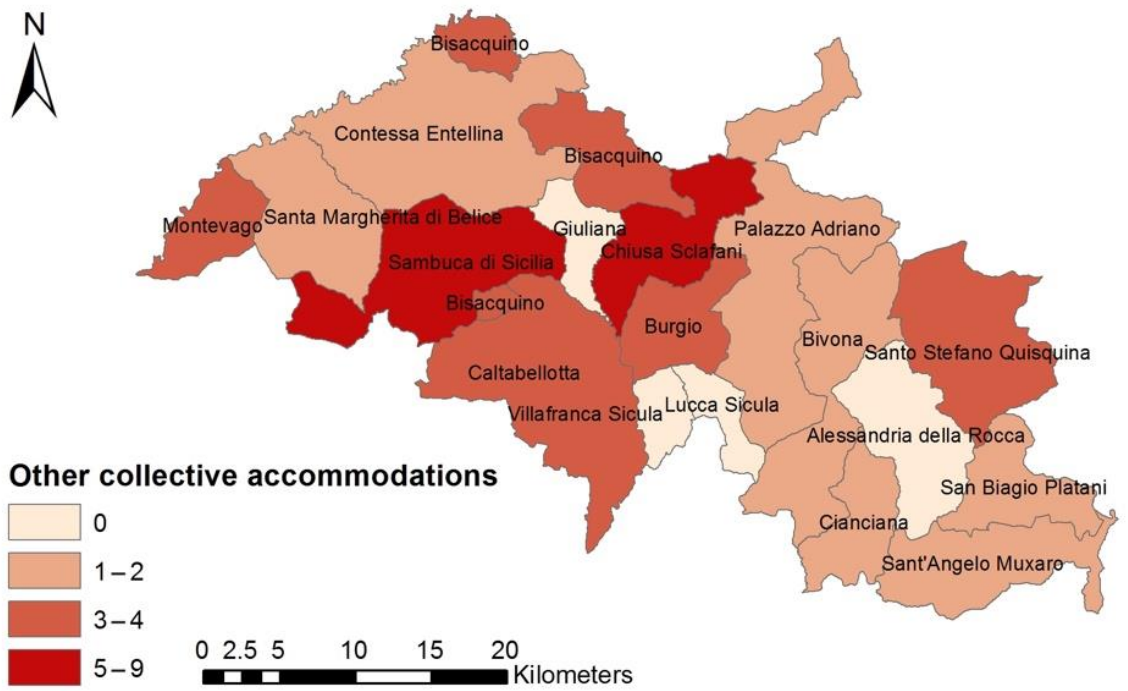

Figure 13. Number of other collective accommodation establishments by municipality, year 2019. Data processing: Osservatorio Turistico-Geoportale Sicilia-del dip. Turismo, Sport e SpettacoloRegione Siciliana (2019). Graphics: Mauro Ferrante.

Table 2 reports information on the number of guests and overnight stays by municipality, along with some tourism-related indicators, such as the average length of stay and occupancy rate, for those municipalities for which information on guests and nights were made available. The analysis of the results derived from official statistics highlights a low degree of the development of tourism activity in the municipalities of the FA for which information are available. The average stay is generally lower than 2 days-the only exception being represented by the municipality of Sambuca di Sicilia, with an average stay of 3.3 days-denoting a typical weekend-oriented tourism characterization in the FA. Even more critical are the data in terms of occupancy rates, with values below $10 \%$ in all cases, the only exception, again, being Sambuca di Sicilia, with a value of $10.6 \%$.

Table 2. Guests, nights, average length of stay, and occupancy rate in collective accommodation establishments, by municipality, year 2019. Data processing: Osservatorio Turistico-Geoportale Sicilia-del dip. Turismo, Sport e Spettacolo-Regione Siciliana (2019). Graphics: Mauro Ferrante.

\begin{tabular}{lcccccc}
\hline \multicolumn{1}{c}{ Municipality } & Establishments & Beds & Guests & Nights & Average Stay & Occupancy \\
\hline Alessandria della Rocca & 0 & 0 & - & - & - & - \\
Bisacquino & 4 & 23 & 53 & 100 & 1.89 & $1.19 \%$ \\
Bivona & 1 & 12 & NA & NA & - & - \\
Burgio & 4 & 72 & NA & NA & - & - \\
Caltabellotta & 4 & 46 & NA & NA & - & - \\
Chiusa Sclafani & 7 & 65 & 300 & 494 & 1.65 & $2.08 \%$ \\
Cianciana & 1 & 10 & NA & NA & - & - \\
Contessa Entellina & 2 & 20 & 47 & 50 & 1.06 & $0.68 \%$ \\
Giuliana & 0 & 0 & - & - & - & - \\
Lucca Sicula & 0 & 0 & - & - & - & $7.78 \%$ \\
Montevago & 3 & 25 & 522 & 710 & 1.36 & $0.22 \%$ \\
Palazzo Adriano & 4 & 57 & 46 & 46 & 1 & $10.60 \%$ \\
Sambuca di Sicilia & 10 & 98 & 1146 & 3793 & 3.31 & - \\
San Biagio Platani & 1 & 6 & NA & NA & - & $7.00 \%$ \\
Santa Margherita di & 2 & 9 & 99 & 230 & 2.32 & - \\
Belice & 2 & 23 & NA & NA & - & 1.75 \\
Sant'Angelo Muxaro & 5 & 94 & 2999 & 5262 & - & - \\
Santo Stefano Quisquina & 0 & 0 & - & - & \\
Villafranca Sicula & & & & - & - \\
\hline
\end{tabular}

Indeed, these results should be taken with care for several reasons. First, for privacy issues, data on guests and nights were not available for six municipalities in the FA, thus not allowing for a complete picture of tourism in the area. Second, and even more important, it is known that a significant component of unobserved tourism derives from the underreporting 
of information on the number of guests and nights, mainly for fiscal reasons. The phenomenon, as the above highlighted, has been proved to be of relevance in the context of Sicily, with estimates of about 1.8 unobserved tourist for each observed 1 [39].

Third, it is likely that most of the establishments in the study area opts for seasonal openings, thus implying values of net occupancy higher than those reported in Table 2. Finally, there are new emerging tourism segments, such as those derived from Airbnb, for which information on the number of establishments, bed places, guests, and nights are not available from official statistical data sources.

Nonetheless, bearing in mind these limitations, tourism activity in the study area, despite experiencing significant growth in recent years, is still at an initial stage, which, considering the natural, historical, and cultural resources offered by the territory of the FA, may represent a potential for development. A deeper analysis of the main reasons for the relatively low degree of tourism development in the FA (e.g., lack of infrastructure, lack of tourism services, lack of promotion, etc.), may help in orienting tourism development policies.

\subsection{Dimension 3: Economies and Values}

The economic-productive sector of the Sicani area is characterised by an important agricultural vocation. The agricultural sector is constantly evolving, not only in terms of production techniques, but also in its ability to no longer limit itself to production alone, looking increasingly to tourist accommodation and new activities. These dynamics are the clearest sign of the potential to create networks rooted in the territory, which connect territorial uniqueness, production excellence, and the people who live in these areas-economically active, diversified networks that can play an important role in regional and national economic dynamics. An analysis of the agricultural use of the territory through the Corine Land Cover databank shows a prevalence of simple arable land, extensive herbaceous crops, and arid calcareous grasslands. In the central part, olive groves, eucalyptus groves, holm oak woods, and conifer reforestation predominate, while in the western part there is a predominance of vineyards (Figure 14).

The excellence of production and a strong link between agri-food excellence and the territory of origin is demonstrated by the presence of important DOP marks (products entered in the Register of Protected Designations of Origin, Protected Geographical Identifications and, Typical Geographical Indications), as shown in Figure 15. DOP-Denominazione di Origine Protetta-indicates a product originating from a region or a country whose quality and characteristics are essentially, or exclusively, due to the geographical environment in which it is produced, such as the wine of Menfi, the wine of Sciacca, the wine of Santa Margherita di Belice, the wine of Sambuca di Sicilia, the wine of Contessa Entellina, and the orange of Ribera). IGP-Protected Geographical Indication-identifies a product whose characteristics depend on the geographical area of origin) such as Bivona peach and Valle Belice wine. PAT-Prodotti Agroalimentari Tradizionali- products are agri-food products characteristic of a territory, of a traditional local production, consolidated and constant, characterised by a normally seasonal offer and that do not have such a strength to enter the circuits of the great distribution) such as the 'Minna di Virgini' (a typical dessert of Sambuca di Sicilia), the spiny artichoke of Menfi, the 'caci figurati' (cheese), the strawberry of Ribera, and the cheese of Santo Stefano Quisquina. 


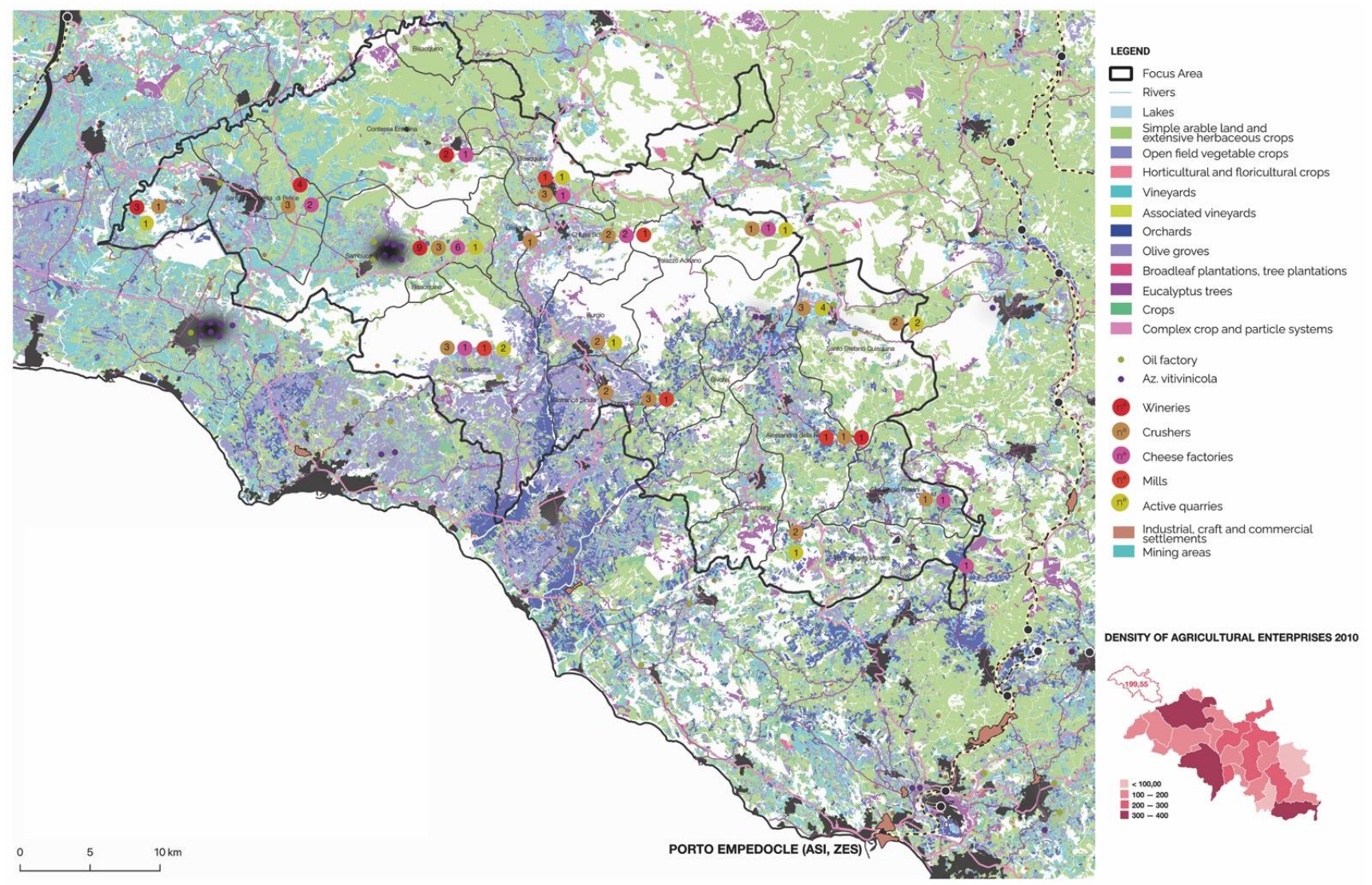

Figure 14. The economic-productive sector. Data processing and graphics: Barbara Lino and Annalisa Contato. Data sources: CTR Regionale Sicilia (1999), Linee guida del Piano Paesaggistico Regionale (PTPR) (1999) Sicilia, Sistema Informativo Territoriale Regionale Sicilia (2021), Copernicus-CORINE Land Cover (2018), on field research.
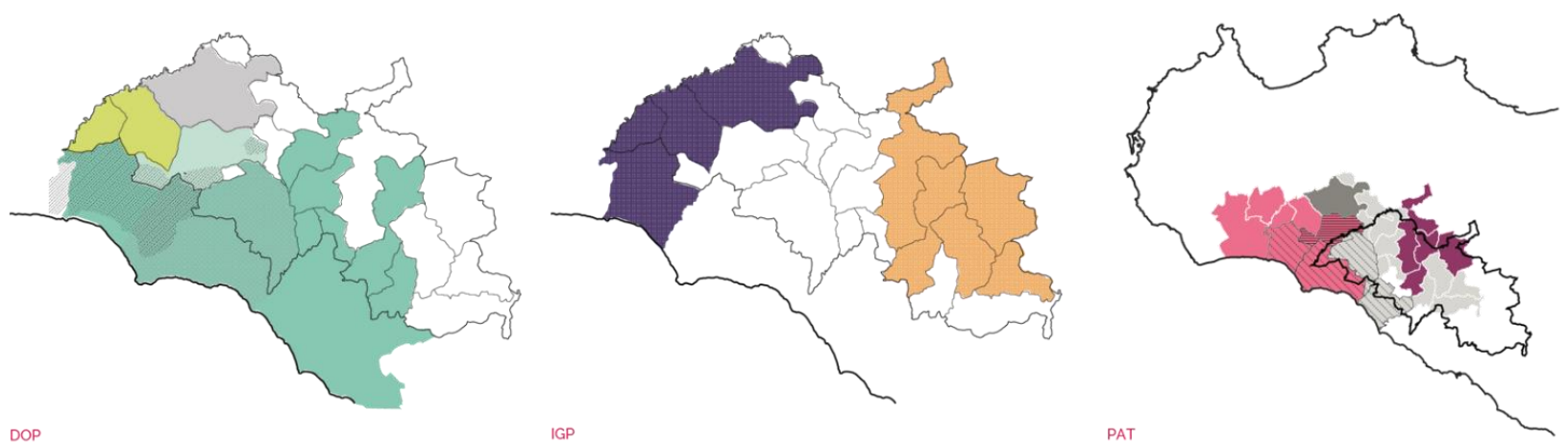

DOP

Wine of Menfi

Wine of Santa Marghertadi Belice

Wine of Sambuca di Sicilie

Wine of Contessa Entellira

Orange of Ribera
IGP

-1. Peach of Bivona
- Minna divirgini

Caci igurati (cheese)

Figure 15. DOP, IGP, and PAT products. Data processing and graphics: Barbara Lino and Annalisa Contato. Data sources: on field research.

As far as the secondary sector is concerned, the area is mainly characterised by manufacturing activities in the construction sector. With regard to the prevalent handicraft and artistic productions, the following should be noted: the municipality of Bivona, for the production of the ancient straw chairs; the municipality of Burgio, for being part of the 'City of Ceramics' network and for the production of wrought iron bells; and, finally, the municipality of Villafranca Sicula, for maintaining the productions with embroidery 
and crochet techniques and for the production of handicraft products such as wicker baskets and handbaskets. As regards the tertiary sector, the main activities are found in the wholesale trade and accommodation and catering services, the latter of which is constantly growing as a result of the development of policies and practices aimed at enhancing the territory through experiential tourism.

\section{Real Estate Market Dynamism of 'One-Euro Houses' and Repopulation Trends}

The analyses carried out in the FA have highlighted the emergence of interesting trends in the recovery of the economic market linked to the real estate sector with a consequent repopulation in some municipalities of the investigated area.

On the one hand, in Cianciana, a spontaneous process has developed over the last 20 years or so in which people from Northern Europe and the United States have settled in the city seeking new patterns of living and working.

In addition to this case, two other municipalities have launched policies inspired by the 'Case a 1 euro' model and with the aim of attracting new residents. That model originated with the initiative of several Italian municipalities which-with the aim of recovering and enhancing the abandoned building heritage of villages and minor centres and facilitating the arrival of new, more or less stable inhabitants—started selling abandoned residential heritage handed over by private individuals to municipalities for a symbolic sum. The initiative is not promoted and structured at a national level, and, as far as procedures, methods, and timeframes are concerned, is decided locally by individual administrations. However, it is possible to recognize a common logic. Private properties in need of major renovation, and whose owners wish to dispose of them (often to avoid paying taxes), are donated to municipalities. By means of a public procedure, the houses are sold at auction starting from a symbolic amount of EUR 1 . Of course, there are commitments that the buyer has to guarantee, such as: providing a renovation project within a certain period of time after the purchase; bearing the notary fees for registration, transfer, and registration; and respecting the maximum time limit for starting the work from the moment permits are obtained.

While the 'One-euro houses' initiative launched in 2020 by the municipality of Bivona is not yet assessable in its outcomes, the most interesting ongoing process can be found in Sambuca di Sicilia. Sambuca di Sicilia was awarded the title 'Borgo dei borghi' (village of villages) in 2016, in an annual competition organised by the national television RAI that has been won already by several Sicilian towns. A great boost for Sambuca di Sicilia has been the 'One-euro houses' initiative for the redevelopment of several buildings in the historic centre. The buildings, owned by the municipality, were sold through a public auction with a symbolic base price of EUR 1, but with a deposit of EUR 5000 to guarantee their renovation and a commitment to complete the work within three years. The aim was to facilitate a process that was already underway, which in recent years has seen around 20 families of different nationalities (Hungarians, Lithuanians, Swiss, Poles, French, and Americans) buy a house in Sambuca and move there as residents (both permanent and temporary). With this initiative, the municipality has aimed to trigger benefits not only from a tourist point of view but also from an entrepreneurial one, through a virtuous mechanism that creates work and development and stops the process of progressive depopulation undergoing in the centres and small villages in the inner areas of Italy.

A total of 16 properties were put up for auction (for a total of 980 square metres), all located in the historic centre, for which 49 purchase offers were received ( 5 offers were excluded because they were received after the deadline). A total of 14 properties were sold, of which 13 were sold to foreigners (Table 3). After the success of the initiative 'One-euro houses', the City of Sambuca di Sicilia in 2021 launched a new call for the sale of municipal property to the tune of ' 2 euros'. 
Table 3. 'One-euro houses' in Sambuca di Sicilia. Data processing: Municipality of Sambuca di Sicilia (2019). Graphics: Barbara Lino.

\begin{tabular}{ccccc}
\hline $\begin{array}{c}\text { Year of Launch of the } \\
\text { 'One-Euro Houses' } \\
\text { Competition }\end{array}$ & $\begin{array}{c}\text { Auctioned } \\
\text { Houses }\end{array}$ & $\begin{array}{c}\text { Total Houses } \\
\text { Sold at } \\
\text { Auction }\end{array}$ & $\begin{array}{c}\text { Houses Sold at } \\
\text { Auction to } \\
\text { Foreigners }\end{array}$ & $\begin{array}{c}\text { Total Number } \\
\text { of Bids at } \\
\text { Auction * }\end{array}$ \\
\hline 2019 & 16 & 14 & 13 & 44 \\
\hline
\end{tabular}

* At total of 5 bids were excluded because they were received after the deadline.

\subsection{Dimension 4: Networks and Services, Community and Governance Models}

The Dimension 4 'Networks and Services, Community and Governance Models' aimed to explore planning tools, governance models, networks, and the policy framework in which the local government of the FA operates, and which determines its relationship with key policy actors and with community and interest groups. However, it also explores the offering of local and supra-local services, the community and its fragility, as well as some innovation trends in place in the territories.

In recent years in the Sicani area, an intense vivacity of the system of local governance has matured that is generating a significant proliferation of programs and an increase in coalitions and networks, evidenced by the birth of LAG, Territorial Pacts, PIT, and the Tourist District, as well as the SNAI.

The analysis carried out shows how the Sicani territory is very active from the point of view of local development planning, as well as the existence of aggregative networks between municipalities with variable geography.

Planning Dynamism

The most relevant result in the Dimension 4 is the 'Map of Planning Dynamism', as shown in Figure 16. In addition to the funds used by the different municipalities in the programming period 2014-2020, the map describes how many municipalities were engaged with supra-local networks as Local Action Groups funded by the Leader+ programme or SNAI in addition. It is relevant in terms of capacity building and opportunity in future development. Starting from the recognition of the planning tools and integrated design, territorial coalitions, and community initiative programs that have been activated in the territory, the 'planning dynamism' of the municipalities of the FA was evaluated, both to better understand the direction of the development of this territory and to verify the presence of existing territorial coalitions. The transversal indicator chosen was the average age of administrators in the FA, checking whether the local project dynamism is related to the age of administrators.

Among the various territorial coalitions resulting from local development programs and community initiatives that have been activated in the territory, the Sicani inner area stands out for its relevance, on the one hand, which is one of the five inner areas of the regional territory identified within the SNAI, and on the other hand, the 'GAL Sicani' (LAG), which has distinguished itself for a lively planning activity developed in the last two programming cycles.

The general objective of the Participatory Local Development Strategy (SSLTP) of the LAG is the strengthening and further development of the Sicani Rural Quality District (DRQ Sicani) established in the previous programming period 2007-2013 (PSL GAL Sicani 2007-2013). The DRQ Sicani is a network of agricultural activities and production of goods and services that through the initiatives and funding of the PSL 2007-2013 has a collective brand in order to certify and enhance local products, natural resources and crafts, and tourism and business activities. 


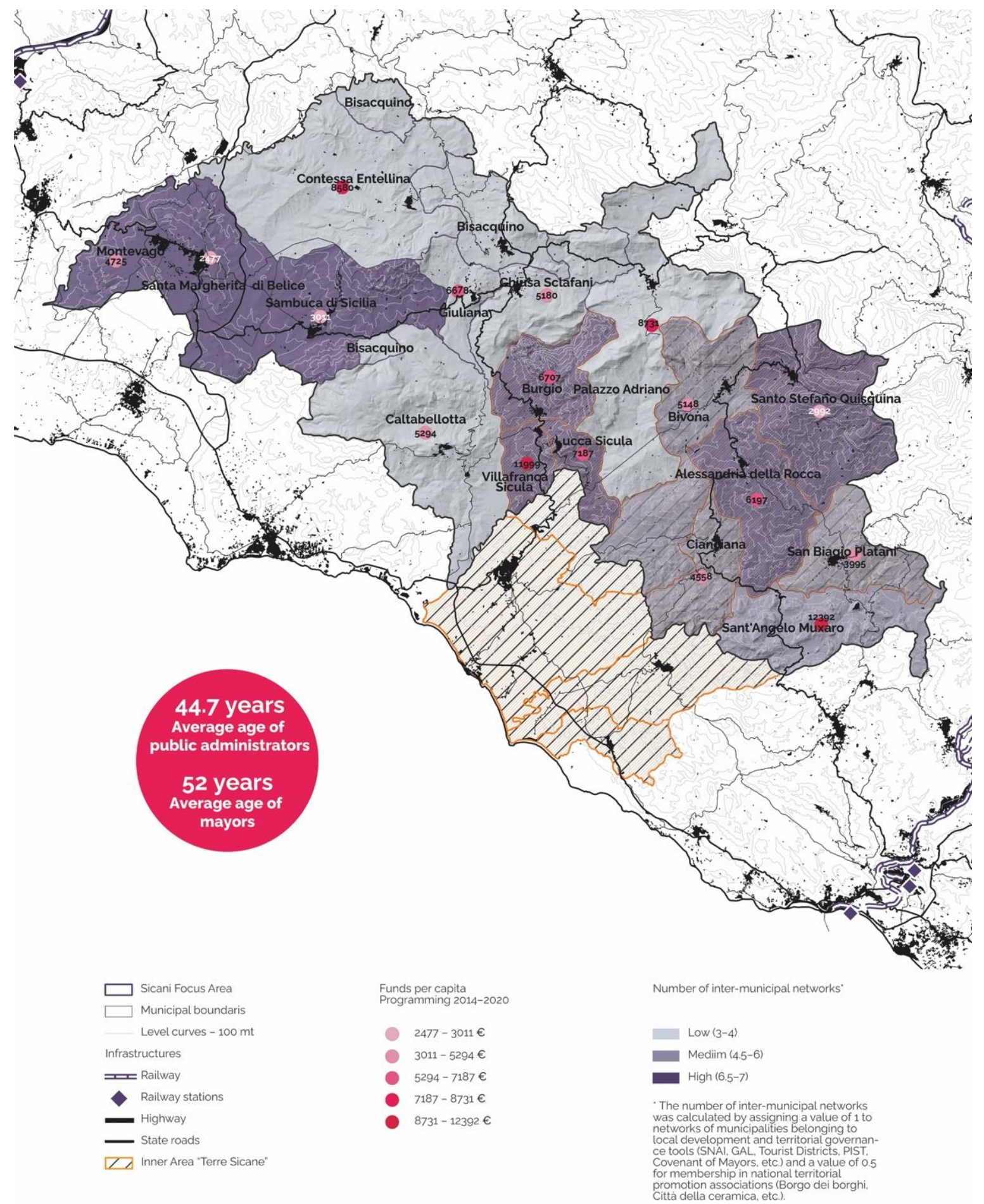

Figure 16. Planning dynamism. Data processing and graphics: Barbara Lino and Annalisa Contato. Data sources: CTR Regionale Sicilia (1999), Sistema Informativo Territoriale Regionale Sicilia (2021), Comuni Italiani (2021), Opencoesione (2021), on field research.

Territorial policies act on different themes and take on different modalities depending on the nature of the program and the dimension in which they intervene (social, economic, infrastructural, etc.).

On the whole, the strategies implemented in the different programs manifest the will to enhance the existing resources (cultural, landscape, natural, productive, and tourist), promoting the territory with the aim of the strengthening its job offering, the strengthening 
of the local production system based on agriculture, the reduction of the migration process in place, and, therefore, the ageing of the population.

The program's policies, while revealing an overall liveliness in the territory, return at the same time a complex and fragmented picture, an area with variable geometry, according to development issues and specific opportunities that from time to time create differentiated control rooms and, more generally, 'spaces of interaction' between public and private subjects, the result of the decline in the territory of different negotiated planning tools.

We underline also that neither the SNAI strategy nor the strategies of the LAG or other territorial coalitions resulting from inter-municipal agreements produce a spatial vision. In addition to the overlapping of different policy instruments, there is a lack of spatialization of the proposed actions and a need for learning to think spatially.

\subsection{Stakeholder Analysis and Interviews Results}

As described, the research relied on the identification and mapping of the stakeholders. This preliminary work was followed by a phase of field research: a campaign of semistructured and non-directive interviews [22] with citizens or representatives of local associations. The aim of the field research was to have a picture of the perceptions of different local actors towards the ongoing development policies and their impact on pre-existing conditions. The 'privileged actors' [22] (p. 55) involved are a mayor, the president of an LAG, an operator in the tourism sector, and two young people with local origins who are part of associations active in the area.

A. Tirrito was elected in 2018 as Sant'Angelo Muxaro's mayor: one of the youngest administrators of the region. Among the territory's weaknesses, he identified the demographic decline, local services insufficiency, and significant rate of underutilized properties. In particular, the mayor denounced the building degradation due to the abandonment and incompletion of buildings. With regard to the elements of innovation, the mayor mentioned some recent innovations: the digitalization of the public administration, an energy efficiency plan, and several urban regeneration projects. In terms of local development policies, Tirrito recalled strategies of local product valorisation and tourism development. Since Sant'Angelo Muxaro has a significant naturalistic and historical heritage, in recent years the GAL Sicani has invested to create a touristic offer inspired by the idea of 'a Sicily of slow rhythms'.

A key player in this process was Val di Kam, a tourist agency based in Sant'Angelo Muxaro that 'has put the foundations for tourism development' in the Sicani territory, making Sant'Angelo a 'pioneer territory'. P. Spoto, founder of Val di Kam, is a hiking guide and territorial animator. His agency proposes a non-traditional approach to tourism inspired by the idea of experiential rural tourism. Experiential tourism is a model of a tourism offer based on 'a non-anonymous encounter between tourists and local operators' [40] (p. 190): an experience that involves entertainment, education, aesthetics, and escapism [41]. Following this model, Val di Kam provides hospitality, food, and experiences: an all-inclusive tour guided by the local insider, a figure 'recognized and recognizable' by the locals. Through the guidance of the local insider the tourists are put in contact with the history of the place and its 'local characters'. The shepherd, the emigrated baker, and the small innovative and organic producer are the protagonists of a play: a place narration accompanies the touristic discovery and fruition. The storytelling transforms the local resources into proper touristic assets, an operation of a 'meaning explanation' of the tourist attractions [40] (p. 92).

This shift from resource to product seems to be the common goal of many stakeholders of the area. The same idea has inspired the Sicani Rural Quality District. Through this project the LAG has elaborated a collective brand for the Sicani's quality products and attractions. The brand was realised to develop an awareness among producers and local stakeholders that local products and attractions are a relevant asset for local development. According to the President of the GAL Sicani, the local development policies still have to better promote the local resources. Communication and storytelling of the territory are perceived as crucial elements in this process. 
Nonetheless, the territory's storytelling is controversial, as the testimonies collected by two young women active in local associations and the LAG testimony. Even if firmly convinced of the need of a strong image of the territory, they both argue that certain representations can be problematic. The two interviewees criticize the romantic narratives describing the inner areas as timeless places: those narratives presenting the villages as idyllic, remote, lost-in-time places populated only by 'romantic shepherds' and picturesque figures. Against this stereotypical imaginary that inspires some of the local development policies, they affirm the need for 'narratives of emancipation': realistic representations involving the perspectives of local actors, especially those who usually are excluded from policy design.

Through this synthetic overview of local actors and stakeholders' perspectives, a certain picture of the territory emerges. On the one hand, the interviews confirm what the local policies describe: the Sicani area is a remote, rural area lacking in facilities and with significant depopulation issues. On the other hand, it seems that due to some initiatives, the area is becoming a destination of rural tourism. It seems that the area is entering the 'involvement

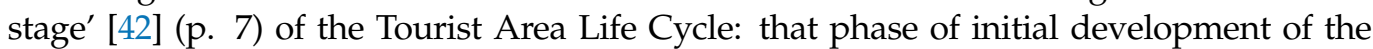
touristic offer run by spontaneous and still not well-organized local actors and stakeholders.

Now this picture is described, it is interesting to point out the imaginaries and perceptions of a specific category of tourists populating the area: the international new inhabitants.

\section{Discourse Analysis and New Inhabitants}

In this section, the analysis focuses on another category of actors: those who in recent years moved to the Sicani area from abroad. Five people were interviewed: M. T.; T. and G. H., who bought houses in Sambuca di Sicilia through the 'One Euro Houses' call launched in 2019; and R. H. and S. T., who moved to Cianciana several years ago on their own initiative. In addition to these interviews, an interview with the manager of the real estate agency Myhouse, who has been managing the sales in Cianciana for years-C. Panepinto-is considered too.

As stated at the opening, the analysis makes use of discourse analysis. In this perspective, discourses build meanings and shape ways of seeing the world. In particular, discourses about places reflect a process of negotiation between different stakeholders. The aim of this analysis is to bring out the recurring themes in the discourse of these actors to outline the imaginary that they project onto the Sicani area. The goal is to understand how these actors represent the territory and their 'spatial practices' [43].

The interviewees come from international metropolitan contexts and are employed in the tertiary sector. Some of them can be considered part of that 'creative class' [44] described as a fundamental element of the economic growth of the post-industrial cities and often responsible for gentrification processes. These elements are decisive in the construction of the imaginary that these actors project onto the Sicani area.

It is important as well to point out how these international people connected with these remote places of inner Sicily. While the call launched in Sambuca di Sicilia had a great success thanks to CNN programs and articles in the New York Times, Cianciana was internationally famous since the early 2000s, when an English writer and journalist moved there and opened a real estate agency, starting a big promotion of the village. On the one hand, there was a very important television network; on the other, there was the mediating resonance of a writer and the following communications made by a local real estate agency through a website, some tourism fairs, and television services. According to several people interviewed, the Cianciana and Sambuca di Sicilia cases happened during the so-called 'redemption' phase of Sicily. After the end of the mafia wars in the 1990s, the region turned into a touristic destination: from the region of 'Mafia and backwardness' to a place rich in treasures, art, and heritage. In this very moment, the Sicani area too has started reshaping its image, becoming a destination of niche rural tourism.

This new representation of the region explains how and why this international target group of people reached the Sicani area. If some of them were driven by a desire to reconnect with family roots, others were looking for a cheap and calm place to move to. In general, all the people interviewed were strongly motivated by the desire of a better lifestyle that the territory 
seems to offer: 'the food, the history, the beauty of the land', M., are frequently recurring elements of the interviewees' discourse. Hospitality is another quality that characterises the territory ('one of the things we like of Sambuca di Sicilia itself were the people!', T.; the 'accoglienza [hospitality] was amazing. I don't know how to say this in English. It's something very local and so unique: accoglienza', S.). Even the idea of the 'small little town' recurs positively, since the interviewees come from very different metropolitan contexts ('very small and quiet', M.; 'safe and timeless', R.). 'The charme of the town' is due to the people, history, culture, and a certain feeling of remoteness that belongs to the territory ('I like being off the grid', M.; 'it's a romantic Sicily here', R.). According to these elements, these people can be considered 'neorurals' [45], a very general definition identifying people who leave urban areas to establish their residence and sometimes employment in a rural area. This term is used to describe very different types of 'return to the land': from the hippie communes of the 1970s, up to recent individual and less politicised experiments. More recently, some have distinguished 'amenity migrants' [46], from 'newcomers' or 'new mountain people' [47] when this trajectory involves mountain regions.

Among the subjects interviewed, we can distinguish different relations to the territory: some spatial practices allow one to better identify them. While some have decided to move to the Sicani, others consider themselves as part-time residents. For this reason, some can be defined as 'rural users' [48]: people similar to tourists that periodically visit rural areas, recurring to temporary accommodations or second homes. Others instead can be called 'new inhabitants' [48]: people who have chosen to live permanently in a rural area, not necessarily for reasons related to their employment but often escaping from a stressful urban lifestyle. In both cases, the interviewees consider it essential to have a good Internet connection: the chance to do smart-working is fundamental to move to the Sicani, although temporarily. In fact, most of these people do not have an occupation based in the territory: most of them work remotely or do freelance creative jobs. Because of its 'charming' and 'inspiring' character, the Sicani landscape seems suitable for those who carry out creative works ('for the creative side, there is so much inspiration in the beauty, in Sambuca di Sicilia and in Sicily in general', G.). The only sectors in which some of the new residents have found employment are the building sector and real estate: activities boosted by the same recent arrival of tourists and foreign residents. In general, it emerges that these people have chosen a 'small little town' for individualistic reasons, often projecting onto the rural context some typically urban lifestyles. In this sense, they can be considered 'practical urban people' [45] (p. 14) looking for a certain degree of facilities and innovation in the rural context. In fact, the arrival of these people has led local administrators to enhance some facilities, especially technologies. For this reason, the presence of these 'neorurals' can be considered an indicator of the transformations that the Sicani area is undergoing more generally.

Concluding, the discourse analysis of these actors confirms that, through the initiative of different actors and stakeholders, the Sicani is becoming a tourist area and a destination for some international élites. This phenomenon deserves to be analysed in depth, investigating the social, territorial, and economic transformations that it can determine.

\section{Discussion and Perspectives: Fostering an Integrated Approach to Build a Shared Development Future Vision}

The study was based on empirical research conducted in the inner area of Sicani in Sicily, Italy. The research investigated the potentials of this marginal territory and of territorial branding in drawing the resilient development of its community, making ruralurban contexts attractive to new residents and users and transforming them into resilient models for communities.

The analyses conducted in the exploration phase of the project made it possible to highlight the stratification of tangible territorial resources (natural areas, cultural assets, infrastructures, historical centres, general services, products of excellence, etc.) and intangible resources (knowledge, local traditions, and forms of innovation), demographic processes of depopulation, and practices and policies for the settlement of new inhabitants. This was 
in addition to transformation processes underway due to the overlapping of aggregative networks, territorial policies, and projects in place.

The mapping carried out made it possible to identify some of the fundamental factors that have contributed to the process of the peripheralisation of the area (physical and digital disconnection, economic and social fragility, and depopulation and ageing), as well as to reveal through a spatialised vision the system of resources of the territory.

Meanwhile, the qualitative investigations conducted through interviews and photographic survey in the field allowed us to integrate quantitative investigations with aspects of qualitative nature.

The aim was to visualise spatial concepts that denote qualities specific to the Sicani area to provide interpretative frameworks of its spatial structure and future development.

In the Sicani area, despite the marginality and lack of infrastructures and services, the analyses carried in the Exploration phase, in particular, showed:

- A stratified system of natural and cultural resources, and hidden and abandoned resources (confiscated assets, disused mines and railways) not yet regenerated or sufficiently enhanced;

- Tourism activity in an initial stage, which, in light of the natural, historical, and cultural resources offered by the territory of the FA, may represent a potential opportunity for development and experiential tourism model experimentation (Sant'Angelo Muxaro and Val di Kam);

- An important agricultural vocation with typical products of excellence and some interesting handicraft and artistic productions;

- The triggering of policies and spontaneous trends aimed at supporting forms of rehousing and regeneration trajectories (e.g., the 'One-euro Houses' initiative in Sambuca di Sicilia and Bivona and the Cianciana spontaneous process);

- A 'charming' and 'inspiring' character suitable to those who carry out creative works and the presence of 'neorurals' as an indicator of the transformation's ongoing trends;

- A collective brand identifying the Sicani's quality productions and tourist attractions as the Sicani Rural Quality District;

- The overlapping in the territories of an increasing number of control rooms, programs, and projects of European and national origin that could be representative of an interesting form of local planning dynamism. On the other hand, these overlaps of polices call for a non-fragmented vision of development that puts more stress on the spatial dimension of policies (SNAI, Rural Development Plans, Local Action Groups, nature reserves and parks, river contracts; etc.).

The choice of applying four themes as 'filters' (the four dimensions) to sound out the resources, values, and criticalities of the territory represented the tool that allowed us to build thematic territorial frameworks of analysis of the full range of assets which play a role in local and regional development. With the four dimensions we tried to unravel the complex tangle of variables related to economic and non-economic resources and material and immaterial endowments.

We are aware that to develop the territorial potential of this area we need to have an integrated perspective on how the different resources and territorial assets might be engaged and managed and a holistic understanding of the interactions between them (or the absence of these interactions that have determined that vicious circle that has blocked the development of the Sicani area).

The processes of development are shaped by the interdependencies between different economic and non-economic factors, and to achieve the objective of the project B4R of developing a shared vision of the development of the area under investigation, therefore, it will be indispensable to assume a holistic and integrated perspective, able to activate interdependencies and relationships between economic, environmental, and social spheres in the local context going well beyond the observation of individual sector components.

A clear vision of the spatial implications to be determined is needed, spatially concentrated interventions for cohesion and development. Through cross-sectoral and spatially 
oriented approaches, integrated urban and territorial policies can act on the relational character of the context through the activation of the latent capital of local resources and the construction of close connections between the community, physical environment, and resources [11].

Indeed, it is precisely on the concept of connections (linkages), of interaction between the parts, and of integration that the project will focus in pursuing in the next phases of its research (Co-design e Co-visioning). (In line with the objectives of the B4R research project, the UniPA Research Unit explored the Sicani territory in November 2021, deepening and promoting a participatory co-design workshop in Santo Stefano Quisquina with the community. The elaboration of the outcomes and results of this phase of the project are in progress and for this reason they are not discussed in this article.) While in the co-design phase the tool of the assembly and integration is the project, in the co-visioning phase the tool of integration will be given by the strategic orientation.

In the co-visioning phase, in particular, B4R will propose a process of strategic spatial visioning to recompose in a coherent territorial vision the system of relationships in place, identifying a branding strategy that can unveil and enable the territorial capital of Sicani (in all its dimensions: natural, cultural, built, financial, social, institutional, etc.) and to increase the community's transformative capacity.

In particular, the notion of territorial capital and the theories related to it are a fertile theoretical field of reference for the research. The concept of territorial capital, initially proposed by the OECD [49], re-proposed by the European Commission [50], and based on authors such as Porter [51] and Camagni [52,53], includes all the resources, both material and immaterial, productive factors, skills, knowledge, and abilities that have accumulated on the territory over time, as well as the set of norms, social relations, and relationality that constitute local identities. Territorial capital that can be best utilised at the regional and local levels includes factors related to local and regional traditions and customs and the quality of governance and informal rules and involves intangible factors such as 'something in the air' or the milieu [54]. The capacity for interaction (connectedness) is a key element of territorial capital, and strategies to ameliorate the challenges of inner areas such as Sicani should therefore seek to enhance the connectivity of the full range of territorial capitals [5].

The Sicani area calls for coherence between separate policies, improving their integration and to stress their spatial dimension. In particular, the lack of a common and strategic vision in the local governance framework will be addressed as key challenge.

The branding strategy of the Sicani area will have to be able to foster a coherent spatial vision of development able to increase the awareness of interaction capacity as a key characteristic of the Sicani's territorial capital, enhancing and connecting material and immaterial resources: in other words, it will need a new development path able to enhance the value of the Sicani's territorial capital.

The results already suggest some exploratory insights and some challenges in the field of policy and design, which can be summarised under these main points:

- Inter-regional connectivity and cooperation between cities, coasts, and marginal areas. The Sicani area needs to be connected to the regional, national, and international flows. This calls for new mobility infrastructures and digital connectivity but also for strategies able to draw new lines of connection, services, and economies that could improve the territory's attractiveness, create shared value, new economies, linking activities, and attracting new populations. Looking at the experiences of relational tourism and new inhabitants, the small centres of the Sicani area can be understood as a premise for a greater cooperation between the coastal area close to the cities of Agrigento-Menfi (south) and Palermo (north) transforming this 'peripheral' territory into an innovative model of living and working.

- Connectivity of proximity. In terms of strategy development, the focus on the interaction and the connectedness of actors seems of decisive influence. This approach invokes at least two dimensions of the challenge: that of strengthening and expanding the interaction space of the full range of actors within the local economy and society to solve the lack of coordination between policies; and that of enabling social innovation 
tracks already in place. About social innovation processes we noticed that in the face of obvious social, infrastructural, and economic disadvantages, in several cases some co-creative communities are already trying to 'diversify locally' by leveraging relevant enabling context conditions, such as a strong local identity in terms of their quality of life, architectural, and natural quality and a general possibility of exploiting social and territorial capital. The particular constellation of people already present-new settlers, temporary citizens, and travellers-suggests that in the Sicani territory the tourism of the future may merge with different work/life models based on multiplace living, new mobility, and digitalisation.

Multiple roles, open and resilient habitats, connectivity, and interaction will need a strong branding strategy to recompose in a choral and coherent vision the ambitions of this community.

Concluding and reflecting on the limitations of this study and future research, it was not always possible to include all the relevant statistical data, which in some cases were not available or not updated (e.g., data on enterprises or on the tourism industry). Thus, a qualitative approach was undertaken (maps with indicators) in some specific fields of investigation, namely the economic dimension and the analysis of tourism demand. Furthermore, the number of interviews with stakeholders was constrained by the COVID-19 pandemic restrictions during the course of this research. The use of on-line interviews partly overcame these restrictions, but with a potential bias in sampling procedures. Given that many national and international contexts may share similar characteristics with the study context here presented, cross-territorial comparisons among different case studies may represent another avenue for future research.

Author Contributions: Conceptualization, B.L. and A.C.; methodology, B.L. and A.C.; data curation, B.L., A.C. and M.F.; writing-original draft preparation and review and editing: 1.1. B.L.; 1.2. B.L.; 2.1. B.L. and A.C.; 2.2. B.L.; 2.2.1. A.C.; 2.2.2. G.F. and F.S.; 3. and 3.1. A.C.; 3.1.2. A.C.; 3.2. B.L.; 3.2.1. L.M.; 3.2.2. M.F.; 3.3. A.C.; 3.3.1. B.L.; 3.4. B.L. and A.C.; 3.4.1. B.L.; 3.5. F.S.; 3.5.1. F.S.; 4. B.L. and A.C. with M.F. on the article's limitations; supervision, B.L.; project administration, B.L.; funding acquisition, B.L. All authors have read and agreed to the published version of the manuscript.

Funding: “B4R Branding4Resilience. Tourism infrastructure as a tool for the enhancement of small villages through resilient communities and new open habitats" (Project number: 201735N7HP) is a research project of relevant national interest (PRIN 2017-Youth Line) funded by the Ministry of Education, University and Research (MIUR) (Italy) for the three-year period 2020-2023.

Informed Consent Statement: Informed consent was obtained from all subjects involved in the study.

Data Availability Statement: The data that support the findings of this study are derived from on field research and resources available in the public domain. Data on "One euro houses" have been provided by Municipality of Sambuca di Sicilia and data on tourism by Osservatorio Turistico-Geoportale Sicilia-del dip. Turismo, Sport e Spettacolo-Regione Siciliana (2019) for this study. About other data sources analyzed during the study see: ISTAT (2020), https:/ / www.istat.it (accessed on 10 March 2021); CTR Regionale Sicilia (1999), https:/ / www.sitr.regione.sicilia.it/cartografia/carta-tecnicaregionale/, (accessed on 22 December 2021); Linee guida del Piano Paesaggistico Regionale (PTPR) (1999) Sicilia, https:/ / www2.regione.sicilia.it/beniculturali/dirbenicult/bca/ptpr/LineeGuida.pdf, (accessed on 22 December 2021); Sistema Informativo Territoriale Regionale Sicilia (2021), (accessed on 22 December 2021); TINITALY (2021), http:/ / tinitaly.pi.ingv.it (accessed on 22 December 2021); Copernicus-CORINE Land Cover (2018), https: / /land.copernicus.eu/pan-european / corine-landcover/clc2018 (accessed on 22 December 2021); ViaMichelin (2021), https: / www.viamichelin.it (accessed on 15 April 2021); Borghi Autentici d'Italia, https: / / www.borghiautenticiditalia.it (accessed on 2 December 2021); Agenzia Nazionale per l'amministrazione e la destinazione dei beni sequestrati e confiscati alla criminalità organizzata (2022), www.benisequestraticonfiscati.it (accessed on 3 January 2022); Ferrovie abbandonate (2022), www.ferrovieabbandonate.it (accessed on 3 January 2022); Comuni Italiani (2021), http:/ / www.comuni-italiani.it (accessed on 23 December 2021); Opencoesione (2021), https:/ / opencoesione.gov.it/it/ (accessed on 23 December 2021). 


\begin{abstract}
Acknowledgments: The authors would like to thank Maurizio Carta (Urban Planning Full Professor, Department of Architecture, University of Palermo), whose expertise was invaluable in formulating the research questions and the methodology in urban planning and territorial policies, and Giulia de Spuches (Cultural Geography Full Professor, Department of Culture and Society, University of Palermo), for her precious support in the supervision of the research for the stakeholder analysis and interviews.
\end{abstract}

Conflicts of Interest: The authors declare no conflict of interest.

\title{
References
}

1. Myrdal, G. Economic Theory and under Developed Regions; Gerald Duckworth \& Co Ltd: London, UK, 1957.

2. Hirschman, A. The Strategy of Economic Development; Yale University Press: New Haven, CT, USA, 1958.

3. Wight, J.B. From Centre/Periphery to Territory/Function: John Friedmann in Transition. In Centre-Periphery Theory: Theory and Practice; Hansen, J.C., Naustdalslid, J., Sewel, J., Eds.; Regional College: Sogndal, Norway, 1983; pp. $24-48$.

4. Naumann, M.; Fischer-Tahir, A. (Eds.) Peripheralization: The Making of Spatial Dependencies and Social Injustice; Springer VS: Wiesbaden, Germany, 2013.

5. ESPON. Processes, Features and Cycles of Inner Peripheries in Europe. PROFECY; Final Report; ESPON: Luxembourg, 2017. Available online: www.espon.eu/inner-peripheries (accessed on 3 January 2022).

6. De Rossi, A. (Ed.) Riabitare l'Italia. Comunità e Territori tra Abbandoni e Riconquiste; Donzelli: Roma, Italy, 2018.

7. DPS-Dipartimento per lo Sviluppo e la Coesione Economica. Strategia Nazionale per le Aree Interne: Definizione, Obiettivi, Strumenti e Governante. Accordo di Partenariato 2014-2020; Dipartimento per lo Sviluppo e la Coesione Economica: Roma, Italy, 2013.

8. De Rossi, A.; Mascino, L. Sull'importanza di spazio e territorio nel progetto delle Aree Interne. In Aree Interne e Covid; Fenu, N., Ed.; LetteraVentidue: Siracusa, Italy, 2020; pp. 48-54.

9. Fenu, N. (Ed.) Aree Interne e Covid; LetteraVentidue: Siracusa, Italy, 2020.

10. Cersosimo, D.; Donzelli, C. (Eds.) Manifesto per Riabitare l'Italia; Donzelli Editore: Roma, Italy, 2020.

11. Carta, M.; Lino, B.; Orlando, M. Innovazione sociale e creatività. Nuovi scenari di sviluppo per il territorio sicano. ASUR 2018, 123, 140-162. [CrossRef]

12. Meloni, B. Aree Interne, multifunzionalità e rapporto con le città medie. In Aree Interne e Covid; Fenu, N., Ed.; LetteraVentidue: Siracusa, Italy, 2020; pp. 142-175.

13. Carta, M. Planning for the Rur-Urban Anthropocene. In Territories. Rural-Urban Strategies; Schröder, J., Carta, M., Ferretti, M., Lino, B., Eds.; Jovis Verlag GmbH: Berlin, Germany, 2017; pp. 36-53.

14. Schröder, J.; Carta, M.; Ferretti, M.; Lino, B. (Eds.) Dynamics of Periphery. Atlas for Emerging Creative Resilient Habitats; Jovis Verlag GmbH: Berlin, Germany, 2018.

15. Ferretti, M.; Schröder, J. Scenarios and Patterns for Regiobranding; Jovis Verlag GmbH: Berlin, Germany, 2018.

16. Lino, B. A New Rur-Urban Utopia? Social innovation and the case of the Sicani area in Sicily. In Territories. Rural-Urban Strategies; Schröder, J., Carta, M., Ferretti, M., Lino, B., Eds.; Jovis Verlag GmbH: Berlin, Germany, 2017; pp. 110-117.

17. Contato, A. The Peripheri-City of the Inner Areas: Local Development in the Sicani Territory. In Dynamics of Periphery. Atlas for Emerging Creative Resilient Habitats; Schröder, J., Carta, M., Ferretti, M., Lino, B., Eds.; Jovis Verlag GmbH: Berlin, Germany, 2018; pp. 192-199.

18. Frazzica, G.; Espa, E. La Valutazione in itinere. In Politiche Pubbliche. Analisi e Valutazione; La Spina, A., Ed.; Il Mulino: Bologna, Italy, 2020; pp. 231-265.

19. Gomes, R. Who Are the Relevant Stakeholders to the Local Government Context? Empirical Evidences on Environmental Influences in the Decision-Making Process of English Local Authorities. Braz. Adm. Rev. 2004, 1, 34-52. [CrossRef]

20. Mitchell, R.K.; Agle, B.R.; Wood, D.J. Toward a Theory of Stakeholder Identification and Salience: Defining the Principle of the Who and What Really Counts. Accademy Manag. Rev. 1997, 22, 853-886. [CrossRef]

21. Winstanley, D.; Sorabji, D.; Dawson, S. When the Pieces don't Fit: A Stakeholder Power Matrix to Analyse Public Sector Restructurig. Public Money Manag. 1995, 15, 19-26. [CrossRef]

22. Losito, G. L'intervista Nella Ricerca Sociale; Laterza: Roma, Italy, 2004.

23. Foucault, M. Les Mots et les Choses. Une Archéologie des Sciences Humaines; Gallimard: Paris, France, 1966.

24. Foucault, M. L'Archéologie du Savoir; Gallimard: Paris, France, 1969.

25. Johnson, M.; McLean, E. Discourse analysis. In International Encyclopedia of Human Heography, 2nd ed.; Kobayashi, A., Ed.; Elsevier: Amsterdam, The Netherlands, 2020; pp. 377-384.

26. D'Anna, G. Paesaggi Minerari in Sicilia: Da Residuo a Risorsa. Strategie e Progetto di Recupero per il Parco Minerario Floristella-Grottacalda. Ph.D. Thesis, Arti e Pianificazione, Dipartimento di Architettura, Università degli Studi di Palermo, Palermo, Italy, 2017.

27. Barone, G.; Torrisi, C. (Eds.) Economia e Società Nell'area dello Zolfo Secoli XIX-XX; Salvatore Sciascia Editore: Caltanissetta, Italy, 1989.

28. Borsdorf, U.; Grütter, T. (Eds.) Ruhr Museum. Natur. Kultur. Geschichte; Klartext Verlag: Essen, Germany, 2010.

29. Barbera, G. Il Giardino del Mediterraneo: Storie e Paesaggi da Omero all'Antropocene; il Saggiatore: Milan, Italy, 2021.

30. Jacob, M. Il Paesaggio; il Mulino: Lavis, Italy, 2017; (Ist ed. 2009). 
31. De Simone, G. "Adaciu": Come andare piano senza perdere la velocità. Una proposta di turismo lento sulle ferrovie dismesse del Belice. Q. CRESM 2008, IV, 24-25.

32. Viola, F. Tracciati di Ferro. L'architettura delle Ferrovie e L'invenzione del Paesaggio Moderno; Clean: Napoli, Italy, 2016.

33. Una galleria per passeggiare. La Riqualificazione della Galleria Ferroviaria tra Albisola Superiore e Celle Ligure (SV): Il Progetto, Tutto al Femminile, di 3sstudio. Domus; 21.10.2011. Available online: www.domusweb.it/it/architettura/2011/10/21/unagalleria-per-passeggiare.html (accessed on 3 January 2022).

34. Fundación Ferrocarriles Españoles. Vias Verdes; National Geographic Institute of Spain: Madrid, Spain, 2021.

35. UNWTO. Recommendations on Tourism Statistics; UNWTO: Madrid, Spain, 1994.

36. Leiper, N. Why 'the tourism industry'is misleading as a generic expression: The case for the plural variation,'tourism industries'. Tour. Manag. 2008, 29, 237-251. [CrossRef]

37. Smith, S.L. Tourism Analysis: A Handbook, 2nd ed.; Routledge: London, UK, 2014.

38. Ferrante, M.; Abbruzzo, A.; De Cantis, S. Graphical models for estimating network determinants of multi-destination trips in Sicily. Tour. Manag. Perspect. 2017, 22, 109-119. [CrossRef]

39. De Cantis, S.; Parroco, A.M.; Ferrante, M.; Vaccina, F. Unobserved tourism. Ann. Tour. Res. 2015, 50, 1-18. [CrossRef]

40. Ercole, E. Turismo Rurale. Sviluppo Locale, Sostenibilità, Autenticità, Emozioni; FrancoAngeli: Milan, Italy, 2020.

41. Pine, B.J.; Gilmore, J.H. The experience economy: Past, present and future. In Handbook on the Experience Economy; Sundbo, J., Sørensen, F., Eds.; Edward Elgar: Cheltenham, UK, 2013; pp. 21-44.

42. Butler, R.W. The Concept of A Tourist Area Cycle of Evolution: Implications for Management of Resources. Géographe Can. 1980, 24, 5-12. [CrossRef]

43. Crosta, P. Pratiche. Il Territorio è "l'uso che se ne fa"; FrancoAngeli: Milan, Italy, 2010.

44. Florida, R. The Rise of the Creative Class: And How It's Transforming Work, Leisure, Community and Everyday Life; Perseus Book Group: New York, NY, USA, 2002.

45. Romita, T.; Nunez Morales, S.N. Nuevas poblaciones rurales: Rural users, trashumantes, nuevos habitantes. Gran Tour Rev. Investig. Turísticas 2010, 2, 4-22.

46. Perlik, M. The specifics of Amenity Migrations in the European Alps. In The Amenity Migrants. Seeking and Sustaining Mountains and Their Cultures; Moss, L.A.G., Ed.; CABI: Wallingford, UK, 2006; pp. 215-231.

47. Varotto, M. Montagne di Mezzo. Una Nuova Geografia; Einaudi: Torino, Italy, 2020.

48. Dematteis, G. Montanari per Scelta. Indizi di Rinascita Nella Montagna Piemontese; FrancoAngeli: Milan, Italy, 2011.

49. OCSE/OECD. OECD Territorial Outlook; OECD Publishing: Paris, France, 2001.

50. Luxembourg Presidency Scoping Document and Summary of Political Messages for an Assessment of the Territorial State and Perspectives of the European Union: Towards a Stronger European Territorial Cohesion in the Light of the Lisbon and Gothenburg Ambitions; Luxembourg. 2005. Available online: http://www.eu2005.lu/en/actualites/documents_travail/2005/05/20regio/ Min_DOC_1_fin.pdf (accessed on 3 January 2022).

51. Porter, M.E. Clusters and the new economics of competition. Harv. Bus. Rev. 2000, 76, 77-90.

52. Camagni, R. Per un concetto di capitale territoriale. In Crescita e Sviluppo Regionale: Strumenti, Sistemi, Azioni; Borri, D., Ferlaino, F., Eds.; FrancoAngeli: Milano, Italy, 2009; pp. 66-90.

53. Camagni, R. Regional Competitiveness: Towards a Concept of Territorial Capital. In Modelling Regional Scenarios for the Enlarged Europe; Capello, R., Camagni, R.P., Chizzolini, B., Fratesi, U., Eds.; Springer: Berlin/Heidelberg, Germany, 2008 ; pp. 33-47.

54. Zonneveld, W.; Waterhout, B. Visions on territorial cohesion. Town Plan. Rev. 2005, 76, 15-27. [CrossRef] 